MISOELLANEOUS

PUBLICATIONS OF THE

EUREAU

of:

GTANDARDS

$112 \cdot 114$ 



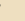




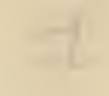




\begin{tabular}{c} 
U. S. DEPARTMENT OF COMMERCE \\
BUREAU OF STANDARDS \\
MANUFACTURE OF INSULATING BOARD \\
FROM CORNSTALKS \\
By O. R. SWEENEY and W. E. EMLEY \\
\hline MISCELLANEOUS PUBLICATION, BUREAU OF STANDARDS, No. 112 \\
\hline
\end{tabular}


$x^{2}=1+2$

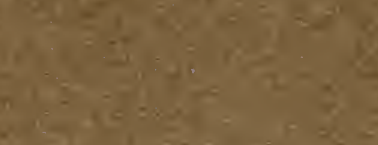

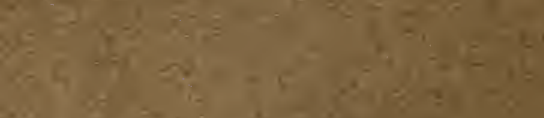

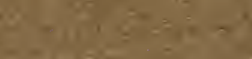

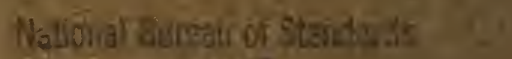

SEP 1 1 1941

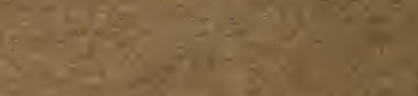

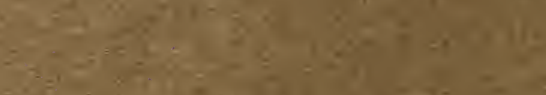

.61 .777

exis $80,2=1$

$26+2=-2+2=8+28$

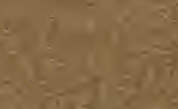

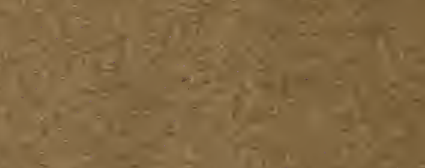

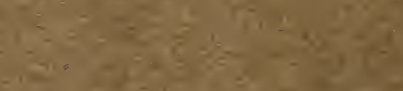

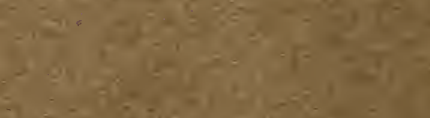

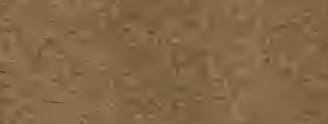

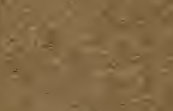

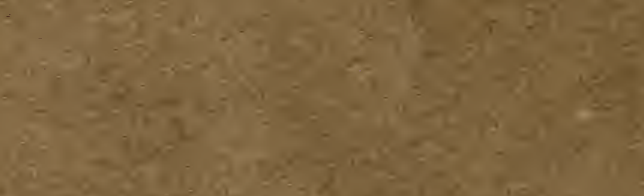

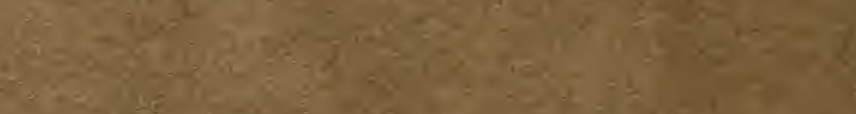

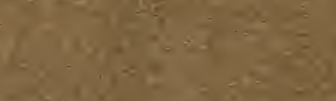

$\because \vdots \because \because \cdots: \because \vdots \because \because \cdots \cdots \cdots$

$\therefore \because \because \because \therefore \therefore \therefore \therefore \therefore \therefore \div$

$\therefore \therefore \therefore \therefore ? \therefore \div$

$$
\begin{aligned}
& x^{12}
\end{aligned}
$$

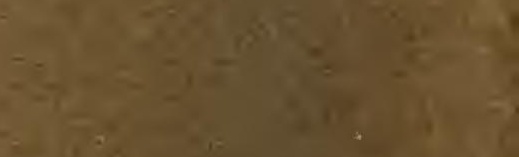




\section{U. S. DEPARTMENT OF COMMERCE}

R. P. LAMONT, Secretary

BUREAU OF STANDARDS

GEORGE K. BURGESS, Director

MISCELLANEOUS PUBLICATION, No. 112

\section{MANUFACTURE OF INSULATING BOARD FROM CORNSTALKS}

BY

O. R. SWEENEY

W. E. EMLEY

October 18, 1930

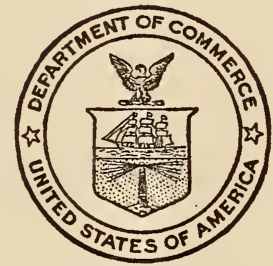

UNITED STATES

GOVERNMENT PRINTING OFFICE

WASHINGTON : 1930 


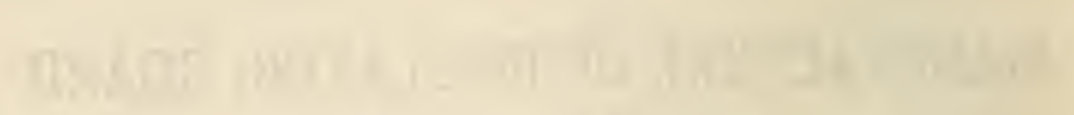

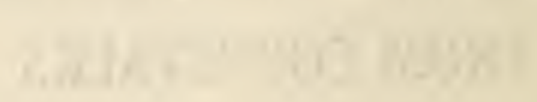




\title{
MANUFACTURE OF INSULATING BOARD FROM CORNSTALKS
}

\author{
By O. R. Sweeney and W. E. Emley
}

\section{ABSTRACT}

Gives detailed data about the location and quantities of cornstalks available, the physical and chemical composition of the stalks and the parts thereof, and the methods and costs of harvesting and baling the stalks and delivering them to the factory. Describes the experimental work on the manufacture of insulating board from cornstalks, from the first laboratory experiments through to semicommercial production, giving details of different ways of making pulp from cornstalks and different types of equipment used to make board from the pulp. Gives test methods and specifications showing quality of the board produced as compared with similar products. Estimates in detail the capital and operating costs for a commercial factory. Analyzes the present and probable markets for insulating board.

\section{CONTENTS}

I. Introduction

II. The corn plant

1. Quantity and distribution

2. Composition and characteristics of the stalk

3. Present value of the stalk

(a) Value as fodder.

(b) Value as fertilizer.

(c) Effect of the corn borer on the value.....

III. Harvesting, delivering, and storing the stalks.......

1. Harvesting and baling

2. Transportation.

3. Keeping qualities

4. Moisture content_...

IV. Laboratory work

1. Introduction

2. Shredding

3. Making the pulp...

4. Sizing

5. Forming the mat.

6. Forming the board

7. Drying

8. Coating

9. Testing and control methods

10. Properties of cornstalk insulating board...

11. Yield.

VI. Related researches

1. Refrigeration board

2. Waterproofing

3. Fireproofing

VII. Cost of manufacture

1. General description

2. Equipment

3. Labor and power

4. Raw materials and output

5. Overhead

VIII. Uses, statistics, and possible competition

1. Uses _. Statistics

2. Statistics

3. Possible competition. 


\section{INTRODUCTION}

In 1927 Congress directed the National Bureau of Standards to study the possibilities of utilizing commercially the waste products of the land. The waste material from the corn plant was selected for the first investigation, because the corn crop provides at present the largest tonnage of unutilized products of any of the annual crop plants.

An extended laboratory study of the corn plant had already been made by the chemical engineering department of the Iowa State College. The results of this work indicated that the manufacture of insulating wall board afforded one of the best opportunities for the utilization of a large tonnage of cornstalks. It consequently seemed advisable to extend this laboratory work to mill experiments on a semicommercial scale, and to this end the bureau was fortunate in being able to enter into a cooperative agreement with the Iowa State College, thus utilizing the background of experience already gained from the laboratory investigations.

Under this agreement the Iowa State College erected a new chemical engineering building at Ames, designed primarily for experiments on wall board manufacture. The equipment was purchased in part by the National Bureau of Standards and in part by the Iowa State College, with very material assistance from the machinery manufacturers.

During the course of these experiments the bureau maintained a staff of four men at Ames, working under the direction of Prof. O. R. Sweeney, of the college staff, and assisted by numerous graduate and undergraduate students. Prof. J. B. Davidson, of the Iowa Agricultural Experiment Station, was of great assistance in developing new types of equipment for harvesting cornstalks.

The work originally planned has been carried to a successful conclusion. The equipment originally selected has been adapted to making a satisfactory quality of wall board at a satisfactory speed. Data have been obtained on the yield and on the cost of manufacture.

It is intended to keep this semicommercial plant in operation in order to try out new types of machinery, to determine if the quality of the board can be improved or its cost reduced and to make such experiments as may be necessary to answer specific inquiries from prospective manufacturers.

\section{THE CORN PLANT}

\section{QUANTITY AND DISTRIBUTION}

The possibility of using cornstalks as the raw material for any industry depends to a large extent on the total quantity available and its segregation in accessible districts.

In 1925 the United States produced corn on 101,631,000 acres. ${ }^{1}$ Much of this land lies in the great Corn Belt, which extends from the Indiana line through Illinois and Iowa to central Nebraska, and includes southeastern South Dakota, northwestern Missouri, and northeastern Kansas. There were more than 100,000 acres of corn

\footnotetext{
1 U. S. Department of Agriculture Yearbook; 1925.
} 
in each of 29 counties in Illinois, 35 counties in Iowa, and 32 counties in Nebraska, and in some counties, mostly in Illinois, more than 250,000 acres per county. In many of these counties more than one-third of the total land area was in corn.

The weight of cornstalks per acre depends upon the climate, soil, variety of corn, and the time of year, and is therefore extremely variable. Reference should be made to reports issued by several State experiment stations (Illinois, Iowa, Indiana, Kansas, North Dakota, Colorado, Nebraska, Ohio, Arkansas, Michigan and Pennsylvania) for detailed data. Actual measurements show from 1 to 3 tons as the weight of stalks per acre, if the stalks are cut at the time when the corn is harvested. If the stalks are not cut at this time, they will gradually lose weight, owing to evaporation of water, pasturage, wind whippage, and other causes, so that the weight in the spring may be only one-half what it was in the fall.

Assuming a production of half a ton per acre (a minimum estimate), and that one-third of the land is in corn, the quantity of stalks procurable within 10 miles of a given point will be 33,000 tons per year. Present experience indicates that a yield of $1 \frac{1}{2}$ tons per acre is not unusual.

\section{COMPOSITION AND CHARACTERISTICS OF THE STALK}

While seven varieties of corn are recognized, only one, "dent corn," is generally raised in the Corn Belt. The leaves and husks of the corn plant form about 28 per cent of the total weight, the stems about 24 per cent, the grain 31 per cent, the cobs 9 per cent, and the root 7 per cent. ${ }^{2}$ The stem is made up of a woody outer wall surrounding a center of pith. The outer wall consists of a large number of fibrovascular bundles covered by a smooth glossy epidermis. Every 8 or 10 inches along the stem the fibrovascular bundles branch out to the leaves, forming nodes at these points. A typical stem is made up (by weight) of about 26 per cent nodes, 53 per cent outer wall, and 20 per cent pith. ${ }^{3}$ The pith is so light that it occupies more than half the volume of the stem.

The chemical composition of the cornstalk, as given by Hopper, is as follows: ${ }^{4}$

Fat

Ash

Crude fiber

Protein

1. 31

Nitrogen free extract

8. 56

34. 51

5. 07

50. 55 (by difference)

100. 00

Considerable variations from these figures may be expected when other samples are examined. The outer shell, pith, and nodes, are all about the same chemically. ${ }^{5}$

2 E. C. Miller and W. L. Latshaw, Elemental Composition of the Corn Plant, J. Agr. Res., 27, p. 845; ${ }^{1924}$ H. W. Wiley, Composition of Maize, U. S. Department of Agriculture Bureau of Chemistry Bu?]. No. 50,1898

T. H. Hopper, North Dakota Agriculture Experiment Station Bull. No. 192; July, 1925

5 C. J. Peterson and R. M. Hixon, Chemical Examination of the Tissue of the Cornstalk, J. Ind. \& Eng. Chem., Anal. Edit., 1, No. 2; 1929. 
For present purposes it seemed necessary to have further information about the chemical composition of cornstalks. The methods for wood analysis ${ }^{6}$ were used with the following results:

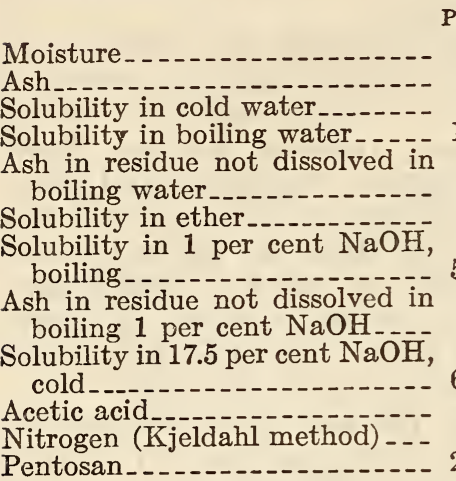

Per cent
9.32
6.20
6.01
18.89

3.24
8.87
53.82

3. 05
60.70
4.36
0.53
27.11

Pentose..
Murfural pethyl pentosan
Lignin (72 per cent $\mathrm{H}_{2} \mathrm{SO}_{4}$
method)
Cellulose (Cross and Bevan
method)
Ash
Pentosan
Methyl pentosan
Alpha cellulose.
Beta cellulose.
Gamma cellulose.
Resistant to 17.5
NaOH per cent
Total alpha cellulose.

Per cent 30. 80 15. 88

1. 39

8. 15

0.05

53. 34

26. 33

16. 57

4. 36

27. 11 56. 14 23. 30

(This analysis was made by H. A. Webber, of the Iowa State Engineering Experiment Station.)

Externally, the nodes appear to be about a quarter of an inch in length and swollen so as to exceed slightly the diameter of the internodes. When viewed internally the nodes are seen to be located slightly below the external nodes. They are made up of closely packed, broad, short fibers and of thick-walled_vessels which serve as conductors for gases and liquids.

The leaf sheaths grow out from the nodes and encircle the stem. In most varieties, the leaf sheaths continue closed for a short distance up the internodes. Within the area covered by the leaf sheath lies the "growth zone," from which the elongation of each internode continues for some time after the stalk has reached mature form.

The relatively long internodes contain numerous fibrovascular bundles distributed symmetrically among a network of parenchyma, or pith cells. The fibrovascular bundles continue without interruption through the nodes and internodes. A cross section of the corn stem through the internode shows that the fibrovascular bundles are more numerous near the outer edge of the stalk, and are strengthened here by many long fibers to make a strong, tubular casing called the cortex. The cortex, covered by the waterproof, silicified epidermal layer, forms in the stem the hard outer portion which corresponds somewhat to the bark of woody plants.

The husk of corn is formed from the leaf which has become specialized to perform this function. The husk, with the ear, is borne on a short stem or branch which consists of a series of very short internodes. At each node a modified leaf emerges to cover the ear of corn. The blades of the modified leaves have been reduced, the leaf sheaths only remaining.

A microscopical study ${ }^{7}$ of the fibers of cornstalks was made on samples from the Agricultural Experiment Station, Ames, Iowa. The fibers were separated by cooking the stalks in an open beaker in a sodium hydroxide solution and by subsequent maceration in a small mortar. This study showed that the longer fibers most useful

A. W. Schorger, The Chemistry of Cellulose and Wood, McGraw-Hill Publishing Co.; 1926.

7 By R. E. Lofton, microscopist at the National Bureau of Standards. 
in the manufacture of paper come from $(a)$ the husk, $(b)$ the leaf and leaf sheath, $(c)$ the cortex layer of the internodes, and $(d)$ the fiber bundles inside the stem. In addition to the fibers mentioned, some of the longer fibers at the nodes and the vessels, serrated and spiral cells probably have some value as paper-making pulp. The pith, or parenchyma cells, the largest of which measured about 0.15 by 0.23 $\mathrm{mm}$ constitute probably 50 per cent of the total volume of the raw material. These pith cells can hardly be considered as fibrous material, but they have some value in the manufacture of paper products.

Microscopical measurements of the lengths and diameters of the fibers from the different parts of the cornstalk were made. The following table gives the averages, the maxima, and the minima of these measurements.

\begin{tabular}{|c|c|c|c|c|c|c|}
\hline \multirow{2}{*}{ Source of fibers } & \multicolumn{3}{|c|}{ Length } & \multicolumn{3}{|c|}{ Diameter } \\
\hline & Average & Maximum & Minimum & $\Lambda$ verage & Maximum & Minimum \\
\hline $\begin{array}{l}\text { Husk } \\
\text { Leaf sheath } \\
\text { Bast (cortex) } \\
\text { Fibrovascular- } \\
\text { Nodes- }\end{array}$ & $\begin{array}{r}m m \\
1.63 \\
1.17 \\
1.65 \\
1.53 \\
.62\end{array}$ & $\begin{array}{l}m m \\
3.91 \\
2.16 \\
2.77 \\
2.68 \\
.92\end{array}$ & $\begin{array}{l}m m \\
0.71 \\
.60 \\
.92 \\
.82 \\
.34\end{array}$ & $\begin{array}{l}m m \\
0.04 \\
.02 \\
.02 \\
.02 \\
.03\end{array}$ & $\begin{array}{r}m m \\
0.07 \\
.03 \\
.02 \\
.02 \\
.06\end{array}$ & $\begin{array}{r}m m \\
0.02 \\
.02 \\
.01 \\
.01 \\
.02\end{array}$ \\
\hline
\end{tabular}

\section{PRESENT VALUE OF THE STALK}

About the only uses made of cornstalks to-day are for fodder and for fertilizer. While a discussion of the value of stalks for these uses is beyond the scope of the present paper, nevertheless the possibility of using stalks for the manufacture of insulating board depends, in the first instance, on the value placed upon the stalks as they stand in the field.

\section{(a) VALUE AS FODDER}

In the Corn Belt only 15 to 20 per cent of the cornstalks are fed to animals. ${ }^{8}$ Whether this is because the cornstalk has little value as a cattle food, or whether there are not enough animals to eat more cornstalks, is immaterial. Let us admit that any industrial utilization of cornstalks should not compete economically with that portion of the production which can find a market as foodstuff and confine our attention to the 80 to 85 per cent remaining.

\section{(b) VALUE AS FERTILIZER}

Most of the cornstalks which are not fed to animals are either ploughed under or burned. The stalks contain about 10 pounds of nitrogen, 6 pounds of phosphoric acid, and 28 pounds of potash per ton. ${ }^{9}$ However, the value of the stalks depends upon many things other than the actual content of these fertilizing materials. Letters to the Cornstalk Products Co., quoted at length by Rommel, ${ }^{10}$ may be taken as official expressions of opinion from Illinois, Wisconsin, Indiana, Ohio, and New Jersey. They indicate that there is still much to learn about the value of cornstalks as a fertilizer. Additional

8 G. M. Rommel, Farm Products in Industry, Roy D. Henkle Co., 1928

9 U. S. Department of Agriculture, Office of Experiment Station Bull. No. 15.

10 See footnote 8. 
studies are now under way at several experiment stations, and it is hoped that specific information will be soon available.

Looking at the matter from the opposite side, we can arrive at a rather definite conclusion. The experience gained through operation of the semicommercial mill indicates that in order to make insulating board profitably, the value of the stalks standing in the field must be not more than 5 per cent of the wholesale selling price of the board. If a farmer thinks his stalks are worth more than this as fertilizer, he should use them for that purpose. He should remember, however, that the labor of disposing of the stalks is also a part of the cost of the fertilizer, whereas if the stalks are harvested to make insulating board the labor can be sold with the stalks.

\section{(c) EFFECT OF THE CORN BORER ON THE VALUE}

It has been decided ${ }^{11}$ that the best method for controlling the spread of the corn borer involves the complete removal of the stalks from the field. Whether it is more economical for a farmer to burn the stalks or to harvest them for sale to some manufacturing industry will depend upon his local conditions.

\section{HARVESTING, DELIVERING, AND STORING THE STALKS}

\section{HARVESTING AND BALING}

In the Ohio experiments cited above 11 different methods of harvesting the corn plant were tried and evaluated. The cheapest method was found to be that in which the corn was picked and the stalks shredded by a harvester consisting of a 2-row picker, with low cutting and shredding attachments, operated by a $30 \mathrm{~h}$. p. motor. The shredded stalks were deposited in windrows on the field. When this machine was owned and used cooperatively by three farmers, the crop was harvested at a cost of $\$ 4.29$ per acre, or, allowing $\$ 2.40$ per acre for the cost of picking the corn, the cost of shredding the stalks and collecting them in windrows was $\$ 1.89$ per acre. The stalks must then be raked up and baled to prepare them for transportation to the factory.

It has been learned from experience that cornstalks can be baled to better advantage if they are whole rather than shredded, and it seems logical to believe that the shredding can be accomplished more cheaply in the factory than by using a portable machine in the field.

In connection with this project, Prof. J. B. Davidson, of the Iowa Agricultural Experiment Station, has directed his efforts toward the development of a machine to cut and bale the stalks. One of the earlier designs of this machine is shown in Figure 1. In its present form, two men using this machine can cut and bale cornstalks at the rate of about $2 \frac{1}{2}$ acres per hour, the bales being dropped on the field as they come. It is probable that additional attachments can be added to pick the corn and to strip off the leaves, if desired. It is necessary to follow this machine with a wagon and labor to pick up the bales and convey them to the main line of transportation to the factory.

11 A study of comparative costs of harvesting corn by present and possible methods to meet corn-borer conditions in the typical Corn Belt States, department of agricultural engineering of Ohio State University and Ohio Agriculural Experiment Station, June, 1926. 


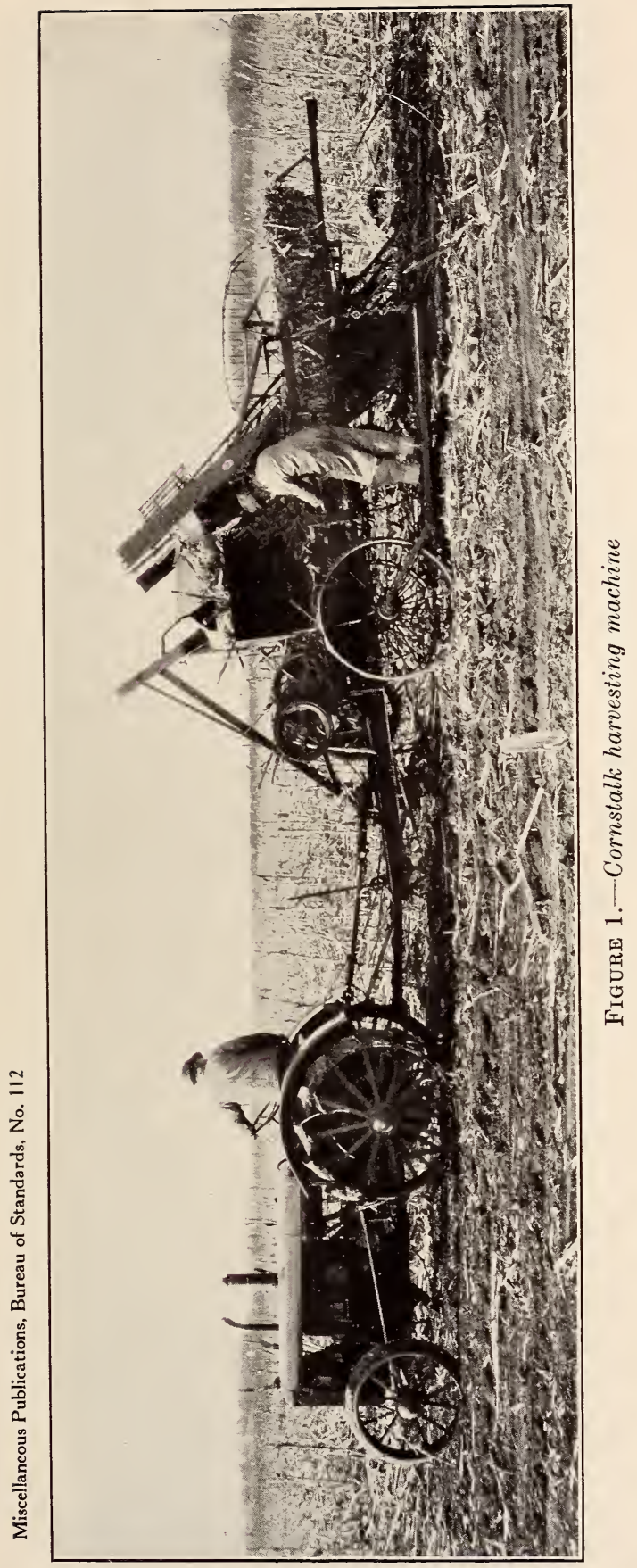




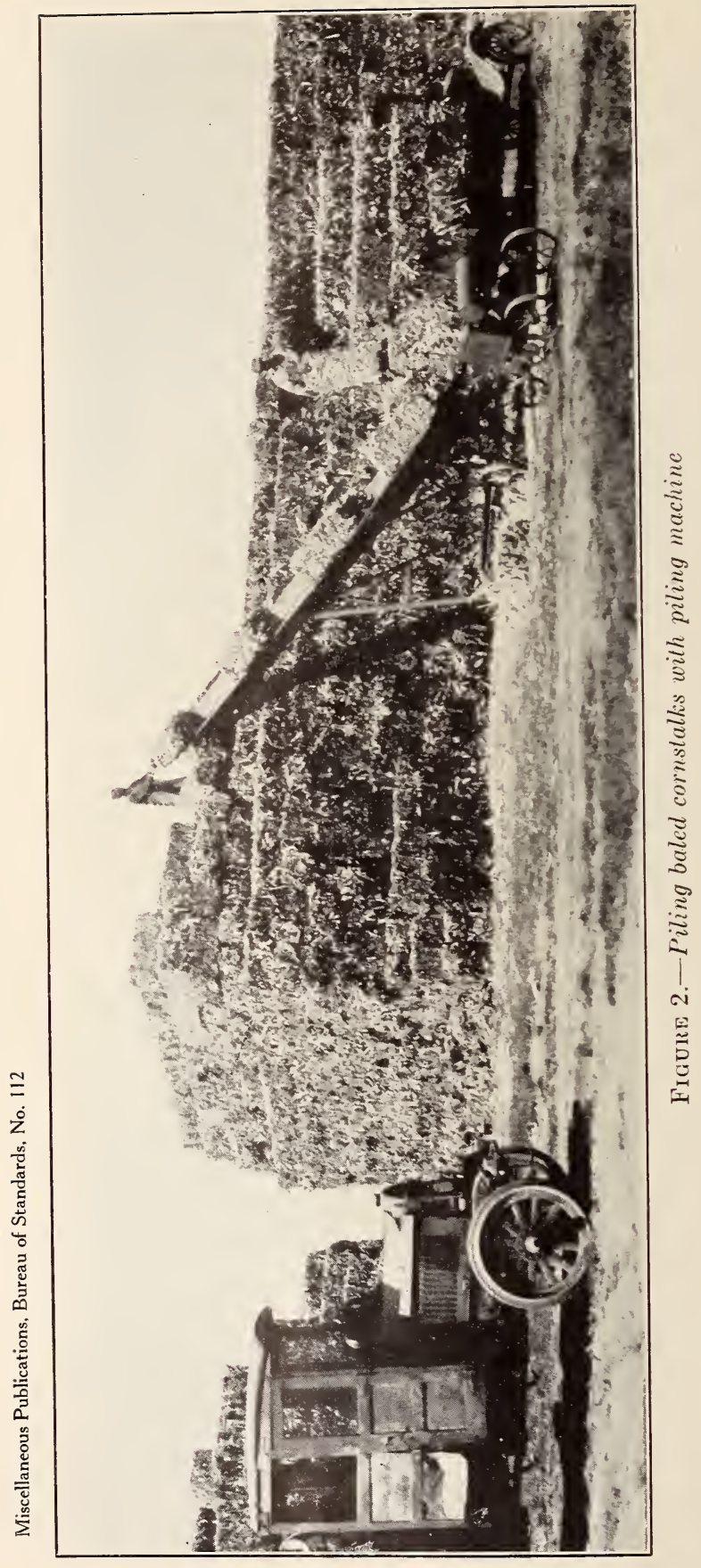




\section{TRANSPORTATION}

The freight rate on baled cornstalks is as follows:

Freight tariff on baled cornstalks

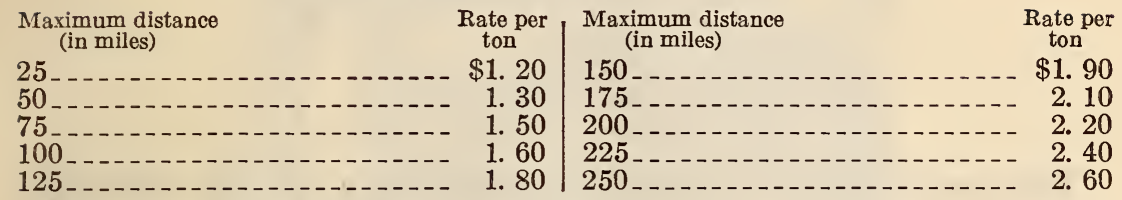

Minimum load 20,000 pounds over one carrier only.

When considering the industrial utilization of cornstalks it is usually predicated that the factory shall be so located as to be able to get its annual supply of raw material within a 5 or 10 mile radius. Under such conditions railroad transportation will not be generally required. The cost of motor transportation for short hauls, as an average for all kinds of roads, is given as $8 \frac{1}{2}$ cents per ton-mile. ${ }^{12}$ By means of a tractor with trailers 11 tons of cornstalks have been hauled in one load.

The agricultural engineering department of Iowa State College has built an inclined elevator (see fig. 2) by means of which baled stalks can be transferred from the truck to the piles at the rate of 4 tons per hour.

\section{KEEPING QUALITIES}

A visual examination of stacks of cornstalks at Danville, Ill., and Ames and Dubuque, Iowa, was made during the summer of 1928. Conditions were quite similar in all stacks. They were usually built flat on the ground without covering, and as a rule had been hurriedly built. In some cases the outside of the stack was built first and bales were thrown into the middle promiscuously, the stack being leveled off as the job approached completion.

Decomposition was apparent in the two top tiers of cornstalk bales. Bales of shredded cornstalks seemed to have decomposed more quickly than those of whole stalks. Below the two top tiers, no marked decomposition was evident until the bottom row was reached on the ground, where again there was serious decomposition. Some stacks had been opened up far into the interior from top to bottom. In these cases the bales were bright and in good condition except for the botton row and the two top rows.

From these observations it is clear that if well-cured cornstalks are stored in stacks which are built on well-drained locations, on foundations which will keep the bottom of the stack free from capillary moisture and drainage water, and if the stacks are covered to protect them from rain and snow, there will be no more decomposition than will be found in a stack of well-cured hay.

Analyses for moisture content of bales of cornstalks which had been standing in the stack for many months were made by Iowa State College with results shown below. Each figure is the average of two analyses.

12 U. S. Department of Agriculture, Office of Public Roads, quoted by Rommel, Farm Products in Industry, Roy D. Henkle Co., 1928.

$2700^{\circ}-30-2$ 


\begin{tabular}{|c|c|c|}
\hline \multirow{2}{*}{ Bales from top- } & \multicolumn{2}{|c|}{ Moisture in sample } \\
\hline & Lot A & Lot B \\
\hline 1 & $\begin{array}{c}\text { Per cent } \\
35.94 \\
10.60 \\
12.50 \\
9.00 \\
10.4\end{array}$ & $\begin{array}{c}\text { Per cent } \\
32.1 \\
15.6 \\
18.5 \\
12.4 \\
16.8\end{array}$ \\
\hline
\end{tabular}

These analyses seem to indicate that the bales at the top, constantly exposed to the weather, act as a seal below which the water does not penetrate.

\section{MOISTURE CONTENT}

The water naturally present in cornstalks decreases their value as raw material for industry. The percentage of water in any particular sample depends upon the ripeness of the stalks when cut, the conditions under which they are stored, and the atmospheric conditions immediately preceding the taking of the sample. It will vary from 10 to 35 per cent from bale to bale, or even from sample to sample from the same bale when taken on different days.

If the bales are all of about the same size, and if they are molded by the use of reasonably constant pressure, it may be assumed that they all contain about the same weight of dry stalks. Counting the number of bales and multiplying by a predetermined factor will give a sufficiently close approximation to the dry weight.

Too much water in the stalks will cause them to heat when closely piled. After two years' experience, we can now state definitely that this heating does not cause any noticeable deterioration of the fiber.

Since the amount of baled stalks which it is possible to put in a truck or freight car is limited by the volume and not the weight of the bales, the quantity of water present has little effect on the transportation cost.

Insulating boards may contain from 7 to 12 per cent of water, depending upon the weather. Some of the water which is bought as cornstalks is therefore sold as board.

\section{LABORATORY WORK}

Beginning about 1920, many graduate and undergraduate students at Iowa State College have conducted experiments on the manufacture of cornstalk boards, under the direction of Professor Sweeney. The equipment includes small grinders, autoclaves, beaters, a rod mill, a sheet-forming device, a press, and a drier.

The experiments were designed to show the relative values of mechanically prepared, cooked, and fermented cornstalks as raw materials for board making. In preparing the mechanical pulp, several different types of shredding and grinding machines were investigated. For the cooked pulp the effects of various chemicals (soda, lime, plain water) and of different temperatures and pressures were investigated. These three types of pulp were mixed in various proportions, both with each other, and with many other materials, such as ground corncobs, peanut shells, flax fibers, cottonwood fibers, peat, calcined gypsum, pulped newspapers, etc. 

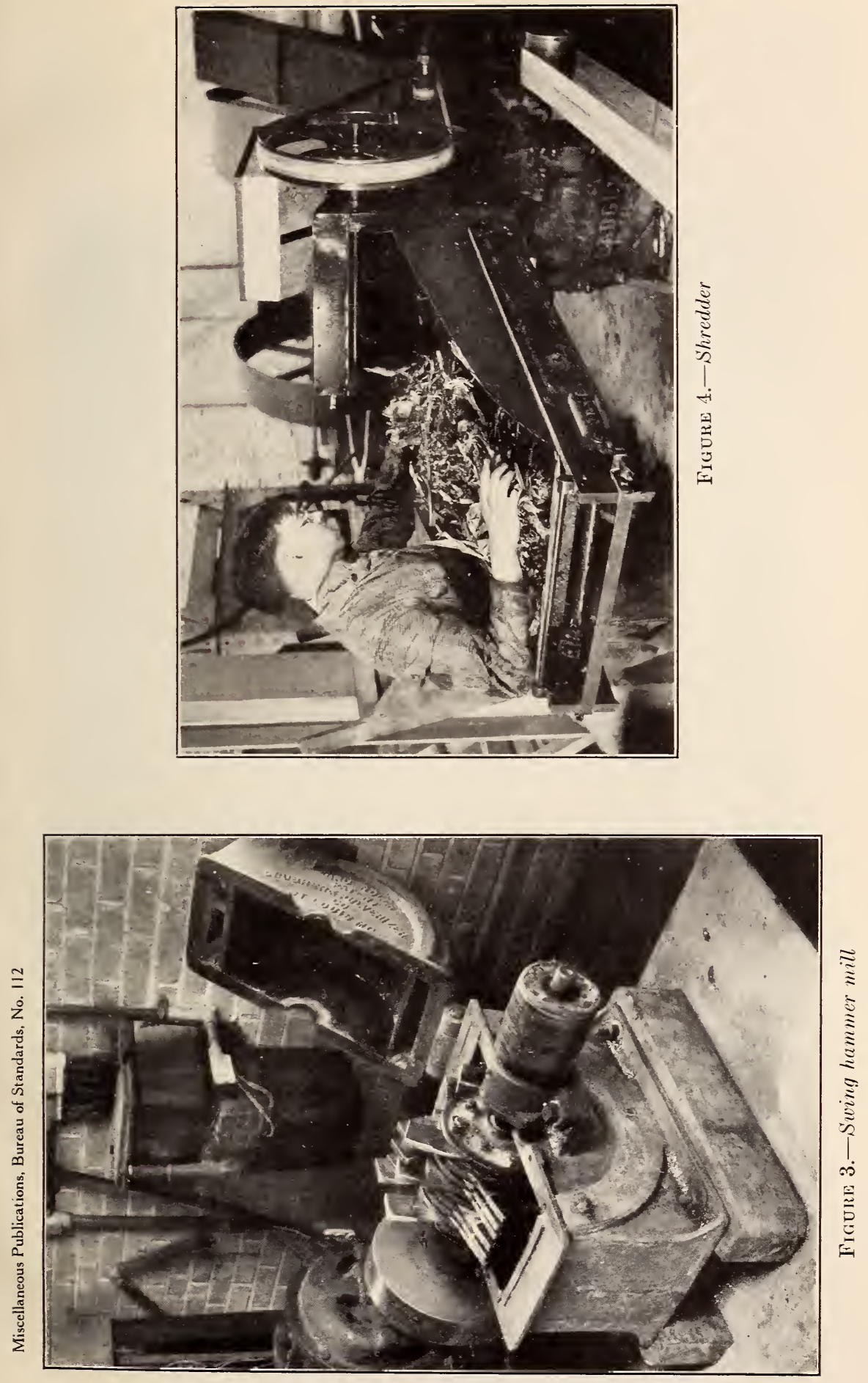
Miscellaneous Publications, Bureau of Standards, No. 112

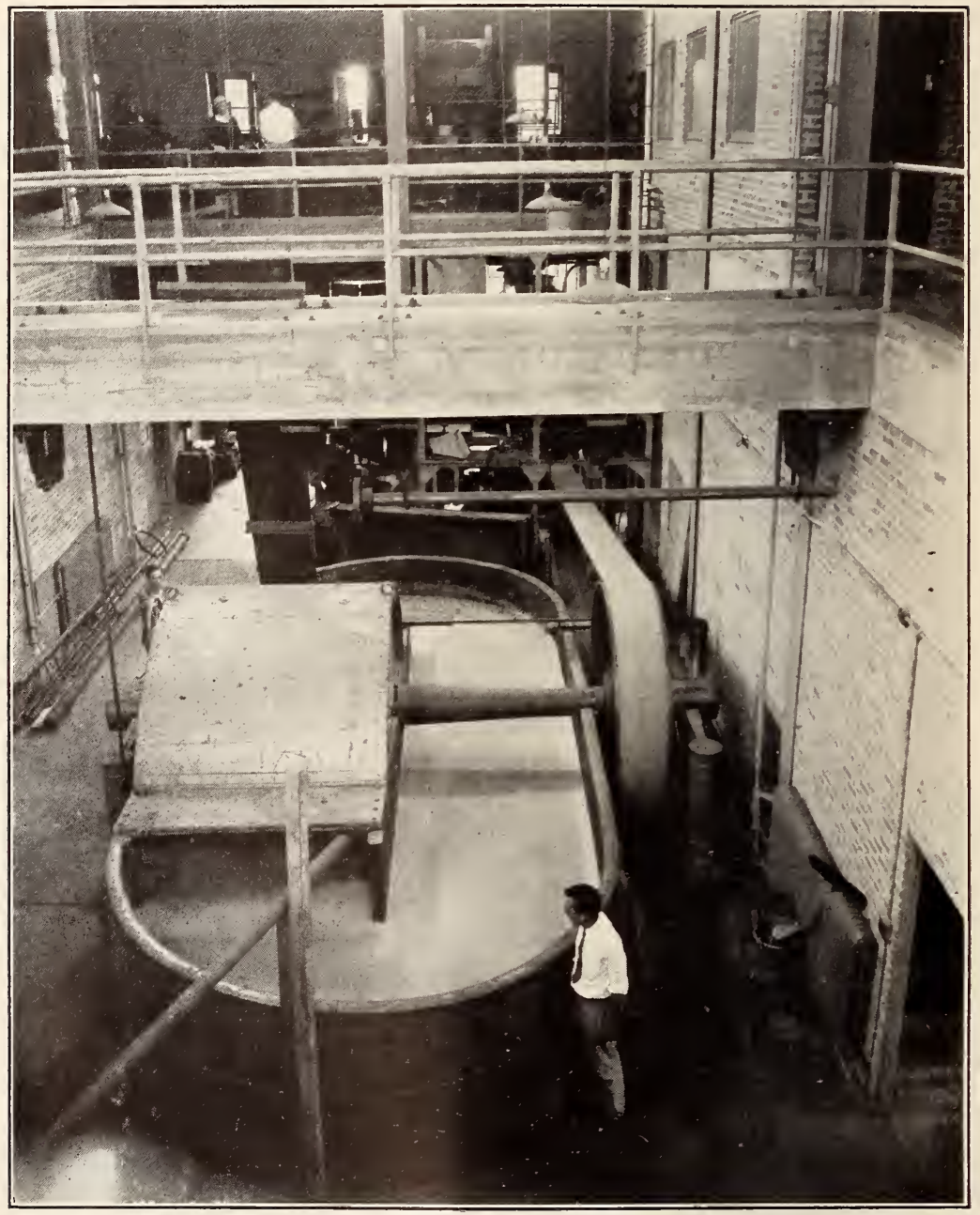

Figure 5.-A 1-ton Hollander beater 
The information obtained from these experiments was invaluable as a basis for deciding many points when the opportunity arrived to design a mill for the manufacture of insulating board from cornstalks. Most of this information is in the form of unpublished theses, but is obtainable from Iowa State College on request.

\section{SEMICOMMERCIAL MILL AND OPERATIONS}

\section{INTRODUCTION}

The study of the manufacture of insulating board from cornstalks had been carried about as far as it could be in the laboratory. It remained, therefore, to put the laboratory process into semicommercial production in order to ascertain by experiment the type of equipment best adapted to the purpose, the yield which might be expected, and the probable cost of manufacture.

It was decided to confine attention principally to cornstalk pulp produced by a wholly mechanical process, but some few runs were made using cooked cornstalks, or other kinds of pulp, as admixtures. As long as the linear speed of board formation is of commercial magnitude, the data obtained can be interpreted, even though the width of the board is less than commercial size. It was therefore decided to design the plant to make a board one-half inch thick by 2 feet wide at a speed of 8 feet per minute. Since the drier could be studied as a separate entity, it was not felt necessary to have a drier long enough to take care of this rate of production.

The general procedure includes the following processes: The stalks are first shredded, then beaten to a pulp with a decided excess of water. After the pulp has been washed, and the sizing material added, it is picked up on a wire screen, which removes most of the water. The sheet of pulp is then passed through a press, which squeezes out more of the water and compresses the sheet to the desired thickness. The sheet then passes through a continuous drier and is cut into the desired lengths, or the sheet may be cut into lengths before the final drying operation.

\section{SHREDDING}

The general process which is used in the production of wall board from fibrous materials first requires that the material be shredded into pieces small enough to be conveniently handled. The cornstalks received from the storage pile were in bales. They were fed by hand into one of the shredders after being sprayed lightly with water to keep down the dust. Three types of disintegrating machines for the preliminary dry shredding were studied. The type of shredder employed made little difference in the quality of pulp produced, provided the sizes of the shredded fibers were approximately the same.

One machine used was the swing-hammer mill (fig. 3), which gave a satisfactory product when a coarse enough screen was used. Better results were obtained when the screen was replaced with cutter bars and the battered pulp allowed to pass through a hinged door. In this case the stalks were shredded wet, since this aided in hydrating the fibers.

In another type of shredder (fig. 4) the stalks were caught between steel pins or knives fixed on the surface of a rapidly revolving drum and stationary pins or knives on the cutting plate. The fineness of 
shredding was regulated by the size of the openings in the screen used on the discharge line. It was found to operate best with the screen entirely removed. This type of disintegrator "pulled a curl" into the stalks and satisfactorily disintegrated them. This shredder was operated at 1,800 r. p. m., and the power required was less than in the swing-hammer mill.

A third type used was an ensilage cutter. It contained rotating knives much like a lawn mower, which cut up the stalks into small pieces as they were projected into the machine through a pair of rolls which held the stalks stiff. The pieces dropped into a chamber in which a rapidly revolving cylinder provided with knives shredded the small pieces and forced them through openings of a suitable size in a screen. Better results were secured without the screen. The power consumption was low. A 15 h. p. motor would grind 2 tons per hour.

In all coarse grinding of stalks it is advisable to spray the stalks lightly with water to keep down the dust. It is obvious that no fine grinding should be done while the stalks are dry.

Machines of all three types have been used in the semicommercial mill. In designing a commercial mill (see Chapter VII below) it became necessary to select one type. The "shredder," shown in Figure 4, was selected, partly because of information obtained in using the machines and partly because of operating data furnished by the manufacturers. However, it should be noted that this selection was more or less arbitrary, and the shredder might prove to be not the most efficient type for the conditions found in a given plant.

\section{MAKING THE PULP}

After shredding, the stalks were either cooked to produce pulp or were reduced mechanically to the proper size. Either the cooked stalks or the shredded uncooked stalks were reduced to a pulp by one or more types of machines. The first machine used for this purpose was a 100-pound Hollander paper beater. A 1-ton Hollander beater driven by a variable-speed electric motor was used later. (Fig. 5.) The small beater was more frequently used, since it was more convenient to handle on small runs. The stalks, together with the required amount of water, were beaten to a pulp of the desired fineness and hydration. The type of pulp obtained depends largely on the way in which the roll is lowered during the beating. When the roll is lowered slowly there is produced a pulp of long fibers, great hydration, and rather high strength. Care must be taken to avoid too great a fiber length, as it will be hard to form the board. Too long beating results in too highly hydrated fibers, which are also difficult to form into a board. If the roll is lowered rapidly, the beater blades cut the fibers rather than brush them out. This gives a much weaker pulp, with the formation of so much fine material that a sludgy mass is obtained which will not form a board. The optimum beating time is between three and four hours from the time charging starts until the beater is emptied. Stronger pulp can be produced by a longer beating time, but it is impractical to do this.

The swing-hammer mill with the proper gradations of screen gives a short, very free fiber, when the pulp is passed through two or more times. This pulp gives an easily formed board which will be too 
Miscellaneous Publications, Bureau of Standards, No. 112

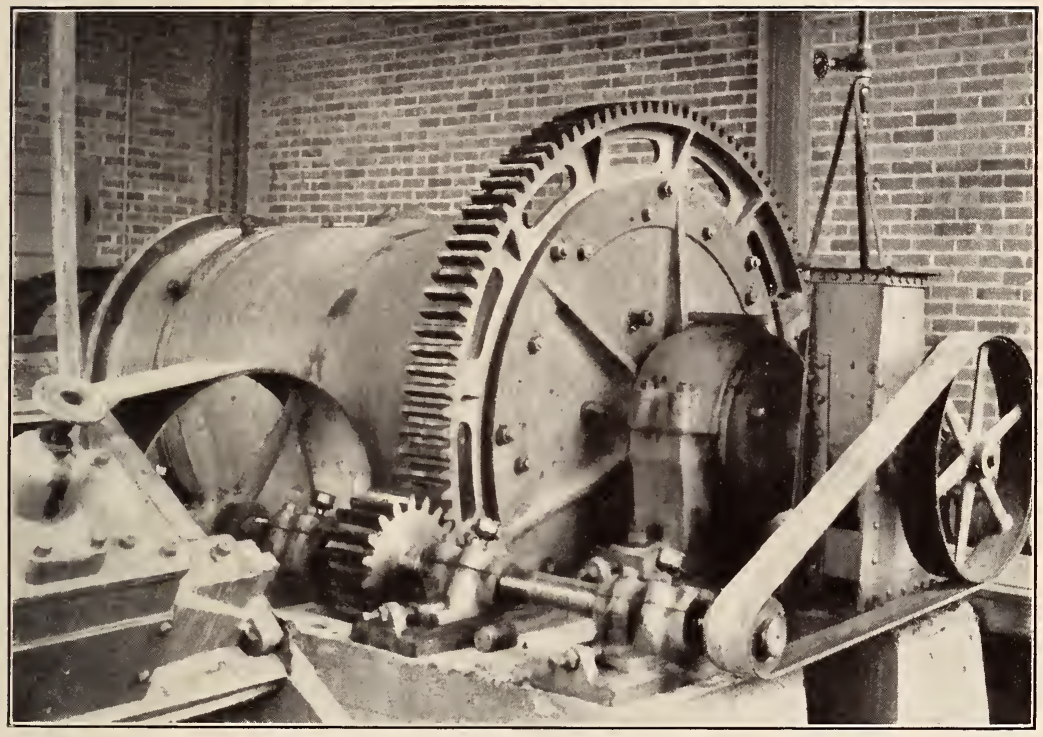

Figure 6.-Semicommercial rod mill 
Miscellaneous Publications, Bureau of Standards, No. 112

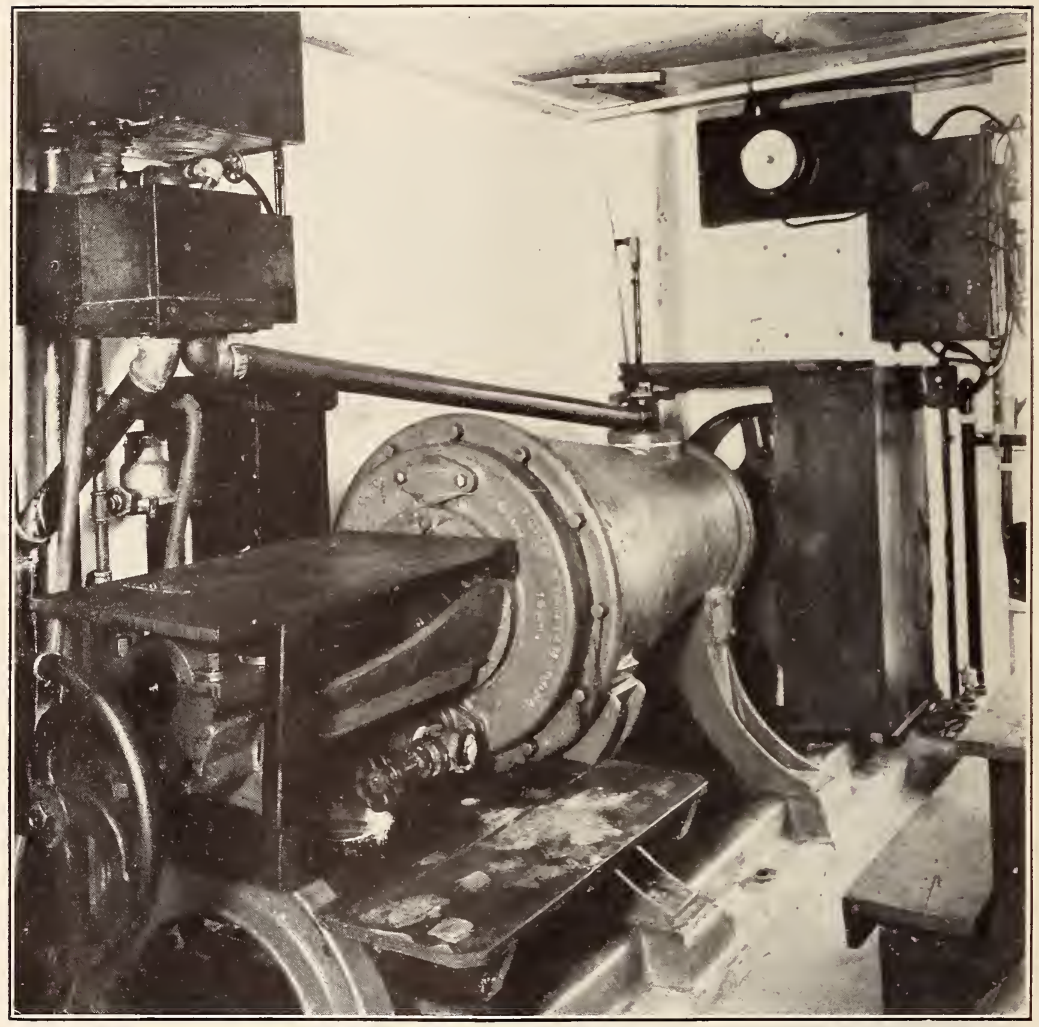

Figure 7.-Jordan 
thick unless the forming period is decreased. Due to the low hydration this board is not strong, usually having a modulus of rupture less than $200 \mathrm{lbs}$./in. ${ }^{2}$. With carefully prepared beater pulps the modulus will be in excess of $250 \mathrm{lbs}$. in. ${ }^{2}$. However, for some purposes such as refrigeration board, the swing-hammer mill pulp is ideal. The swing-hammer mill used was a very small model, so that the results are not necessarily directly convertible for use on larger sizes or different types of mills.

A rod mill (fig. 6) about 4 feet in diameter by 6 feet in length was used for a few experiments. The mill could be operated at variable speeds and continuously or intermittently. In the rod mill the shredded stalks in suspension in water were subjected to alternate compression and release produced by the falling rods. The stalks were run through one or more times and then run to the beater. The rod mill as a pulping machine for cornstalk pulp is still in the experimental stage. Some of the best types of board produced in the laboratory have been made from rod mill stock. The pulp is of rather coarse texture if it makes only one passage through the rod mill. If, however, 2, 3, or 4 passages are made, the pulp is hydrated to a high degree and has a fine texture. It is believed that the rod mill may be the proper machine for processing the cornstalk pulp, and further experiments on its use are now under way. Not over 200 pounds per hour have been passed through the laboratory mill on the first passage. This is partly due to the fact that the feeding device is not properly worked out. After the pulp has been passed through the mill once, it can be passed through again at an extremely rapid rate.

The best pulp prepared to date in the laboratory was made by first passing it once through the rod mill and then ejecting it onto a screen where the stalks were thoroughly washed. The pulp was then run through a Jordan refiner. The mill used in the laboratory was the smallest commercial size rod mill made, requiring about $15 \mathrm{~h}$. p.

A Jordan engine was used as a refiner after other operations. The machine used in the laboratory was a small experimental machine (fig. 7), which was slow for such coarse work. Provisions are being made to test out a modified Jordan machine, such as a Claflin refiner. The brushing action obtained in revolving-disk machines containing either steel or stone disks was not very satisfactory. It was not possible to obtain a Bauer attrition type of machine for the laboratory, but this machine was observed in operation at other places.

Except with very clean stalks, it is necessary to wash the pulp to remove the dirt and fine material whicb interferes with the board formation. The washing increases the freeness or rapidity of filtration of the pulp. The method employed was to use a small hexagonal washer on the beater or to screen off the water by means of screens as the pulp came from the various machines. A small rotary screen was also used. Mixtures of various types of pulp gave boards with properties intermediate to those from the constituent pulps. By adding newsprint an increase in strength can be secured. The newsprint increases the density which tends to decrease insulating properties. For this reason it is not practical to add over 10 per cent.

When using an Oliver board-forming machine, such as was used in this laboratory, the freeness for a $1 / 2$-inch board must be between 50 and 450 seconds. The most satisfactory results are secured with a freeness between 100 and 200 seconds, although there are other 
factors which influence the formation of the board, such as kind of pulp, consistency, and the setting of the Oliver.

Chemical pulp.-For cooking the stalks, a stationary vertical type digester equipped with an agitator driven from below, with means for direct and indirect steam heating, was used. It had a capacity of 75 cubic feet, or about 300 pounds of shredded cornstalks, and could be charged at the top through a manhole and emptied through a door in the side.

Cooked pulp has been prepared at Ames by a variety of methods. Stalks were cooked in water alone at 40 pounds steam pressure for one-half to six hours. This gives a very satisfactory board. Other good boards have been made from a mixture of this pulp with mechanical pulp. Stalks have also been cooked with various chemicals, such as lime, soda ash, soda ash and lime, caustic soda, soda ash and sulphur, lime and sulphur, sodium silicate, and sodium sulphide. Yields from cooked pulp vary from 90 down to 35 per cent, depending upon the chemical used, the concentration, and the length of the cook. About 12 pounds of water were used to each pound of bone-dry fiber in all the cooks. A large amount of unpublished information is available as the result of the work at Ames on the cooking of cornstalks and the manufacture of paper therefrom.

It should be borne in mind that almost any pulp will make a board of good insulating value and good appearance. The principal study is to produce a pulp which will make a light, strong board which is easily formed on the machine.

\section{SIZING}

Insulating board should be sufficiently resistant to the absorption of water so that it will not suffer permanent deterioration when exposed to ordinary conditions of humid air. For this purpose a certain amount of sizing is required.

In the paper trade, the sizing material generally used is a combination of rosin and alum. These materials are added to the pulp in the beater. The rosin is used as a soda-rosin soap, which is slightly alkaline; the alum is slightly acid. The degree of sizing obtained in the paper is very sensitive to the alkalinity or acidity ( $\mathrm{pH}$ value) of the mixture of the two.

The commercial rosin size used had the following composition:

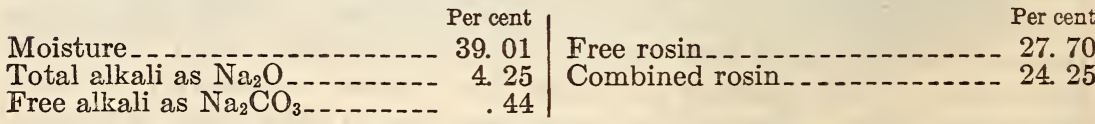

The alum used was commercial aluminum sulphate, added in the form of a 15 per cent solution in water.

A predetermined amount of size was added to the pulp in the beater. This was followed by the amount of alum required to bring the $\mathrm{pH}$ to the desired value. Board was then made from the pulp and tested for the degree of sizing. For this purpose both the "spot" and "floating" test methods were used. In the former, $1 \mathrm{ml}$ of a dilute dye solution was dropped on to the surface of the board, covered with a watch glass to prevent evaporation, and the time required for complete absorption of the liquid was noted. In the latter a sample of board 7 by $2 \frac{1}{2}$ inches was permitted to float on the surface of water, 
and the gain in weight noted at frequent intervals. Both of these methods are admittedly crude, but they have proved useful as rough and ready means for factory control. In this case, the results obtained by both methods checked each other fairly well, and it was found that the most effective sizing was obtained when the rosin size and alum were used in such proportions as to give a $\mathrm{pH}$ of about 4.5.

Further experiments, the results of which are shown in Figure 8, indicated that there is little to be gained by using more than 2 per cent of the rosin size, based on the dry weight of the fiber. Some incidental experiments, in which boards were made of pine chips con-

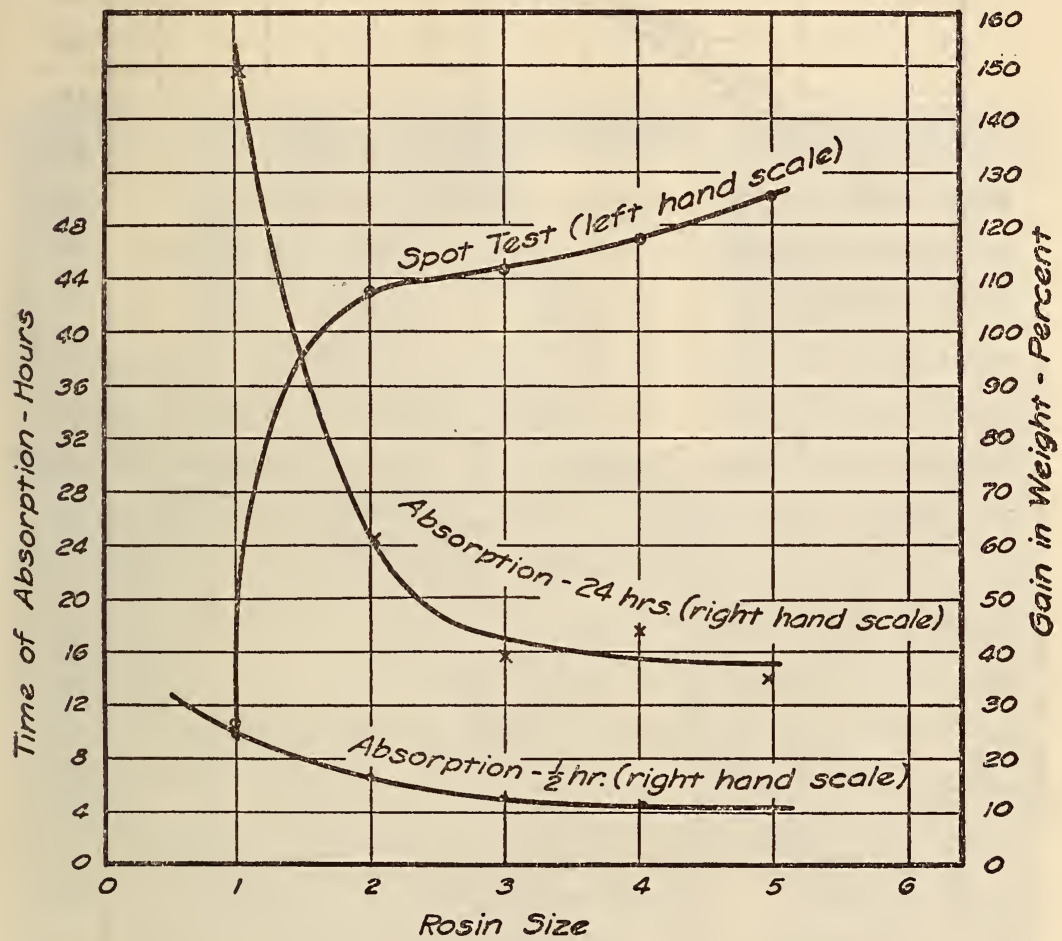

FIGURE 8.-Amount of rosin v. degree of sizing

taining 5.5 per cent rosin as received, showed that with such material additional sizing is hardly necessary.

Since the manner of drying the board has been considered as determining in part the degree of sizing obtained, ${ }^{13}$ this factor was investigated by drying boards at different temperatures. Some of the data are shown in Figure 9. From these data it is concluded that the drying temperature has little effect on the degree of sizing within the limits studied.

Many other types of sizing materials were studied. An attempt was made to use sulphuric acid as a substitute for part or all of the alum. Glue, sodium silicate, starch, casein, soybean casein, alkagel, and an adhesive made from corncobs were used either alone or in

\footnotetext{
${ }^{13}$ Sutermeister, E., Chemistry of Pulp and Paper Making, Wiley; 1920.
} 
various admixtures. Combinations of some of these (notably 5 per cent starch plus 5 per cent sodium silicate) gave well-sized boards, but are generally too expensive. These experiments showed, therefore, that the ordinary rosin-alum size is about the best to be had for the purpose.

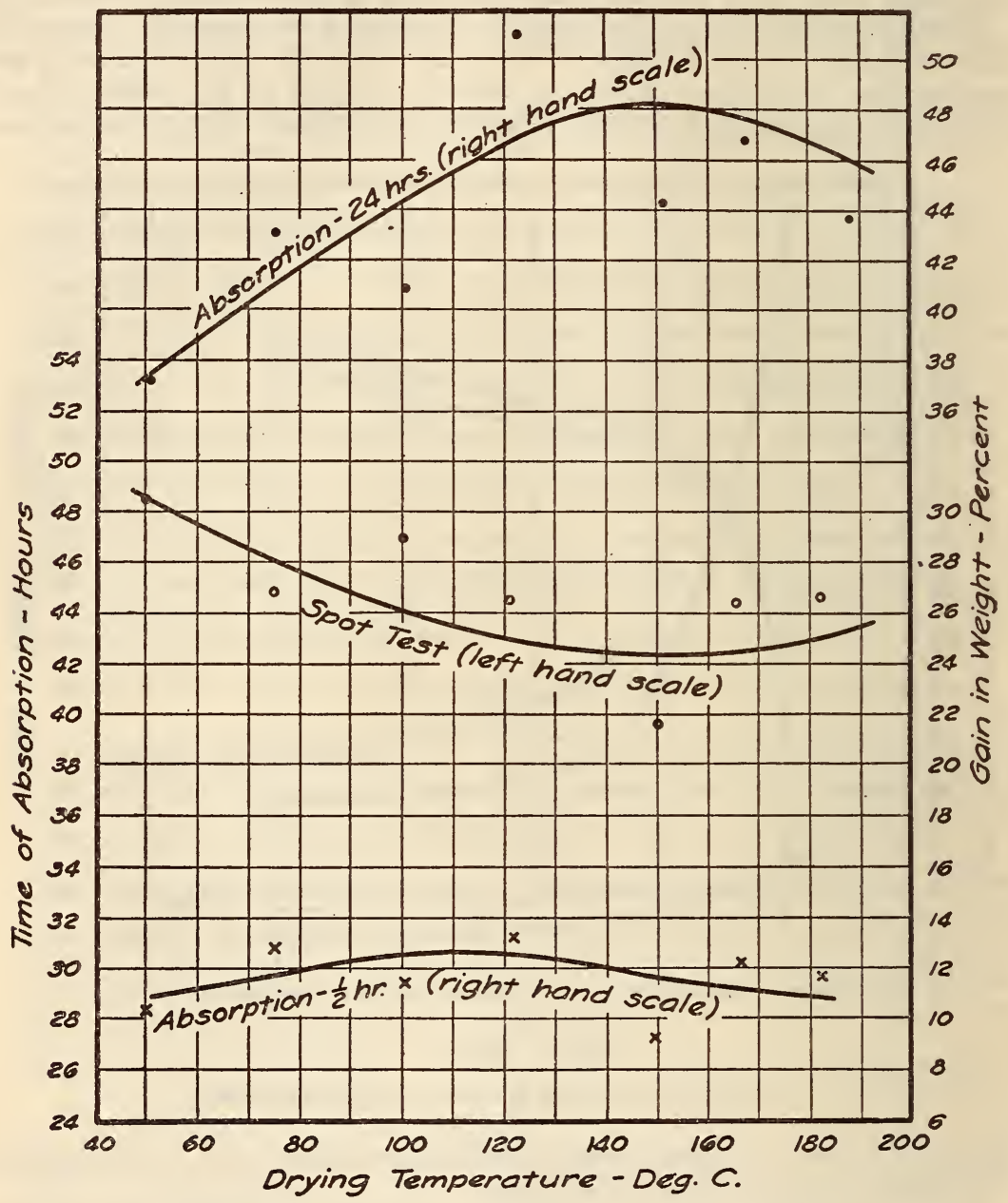

FIGURe 9.-Temperature of drying $v$. degree of sizing

\section{FORMING THE MAT}

In the paper industry there are two types of machines in general use for forming the mat-the cylinder and the Fourdrinier. A modified Oliver continuous filter shown in Figure 10, with a drum 36 inches in diameter by 26 inches wide, was installed. This is somewhat similar to the cylinder type.

In this machine a hollow drum covered with a fine screen rotates in a rectangular tank. The inside of the drum is divided into compartments by longitudinal partitions extending from the rotating axis outward to the periphery. These compartments are so connected 
Miscellaneous Publications, Bureau of Standards, No. 112

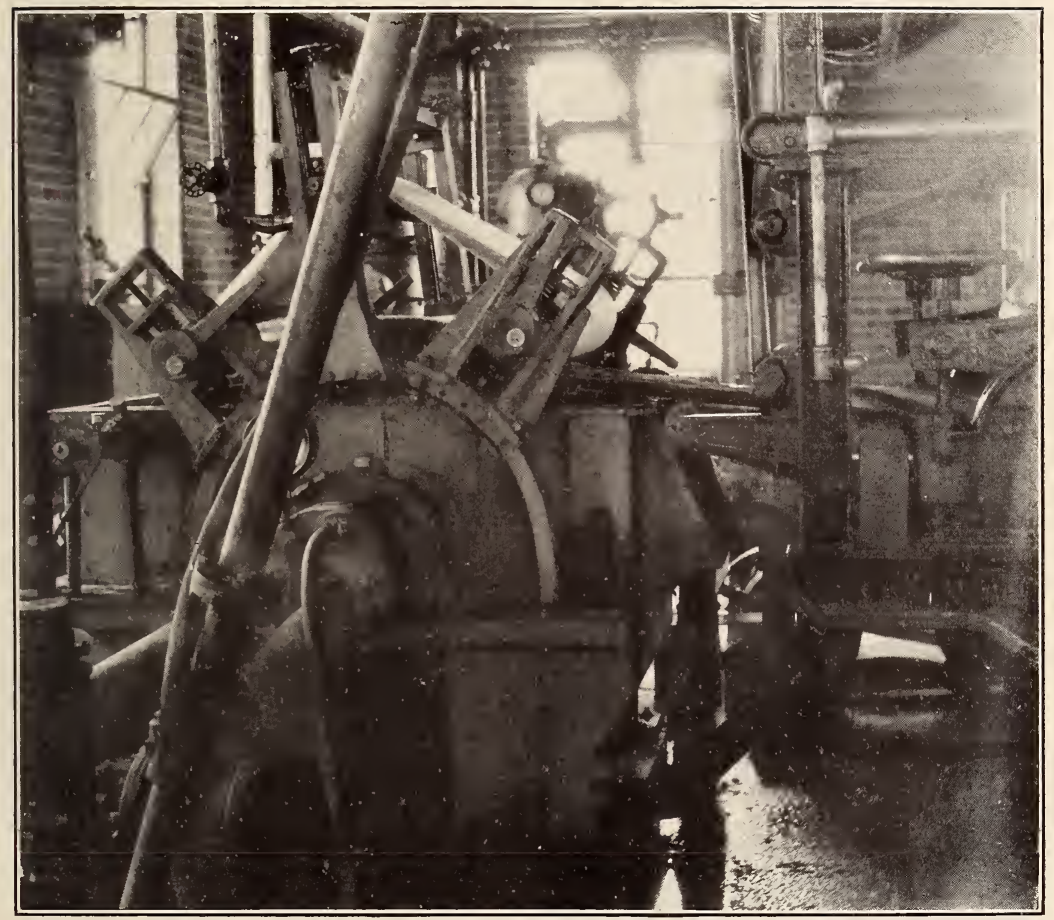

Figure 10.-Mat-forming machine 
Miscellaneous Publications, Bureau of Standards, No. 112

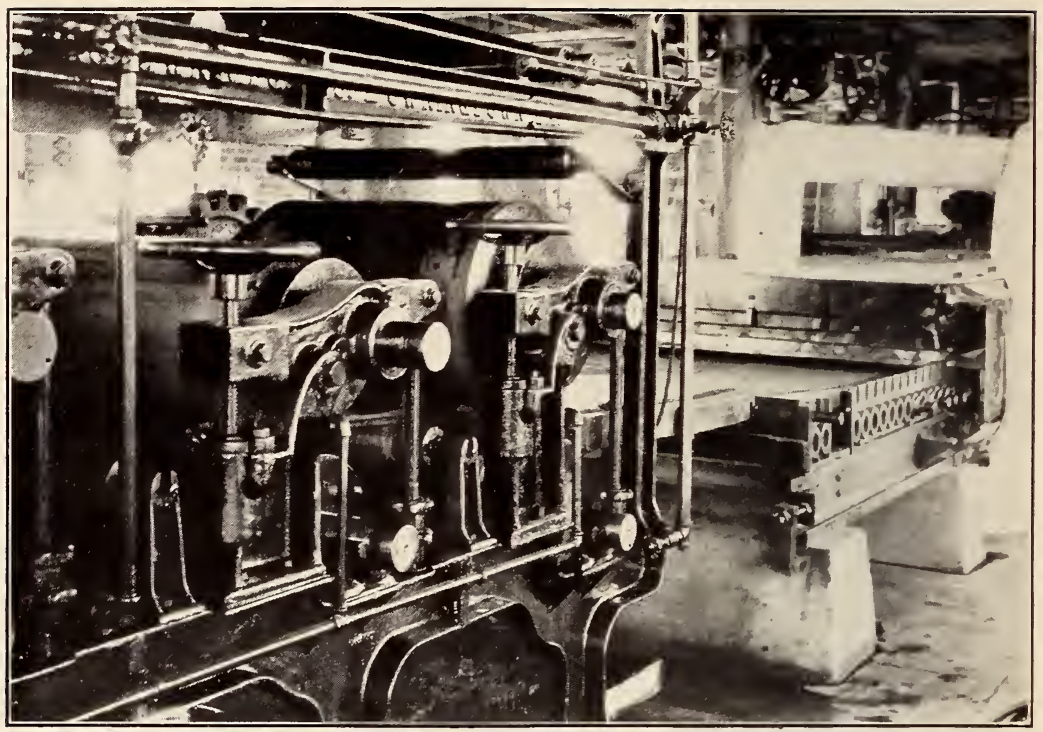

Figure 11.-Board-forming machine

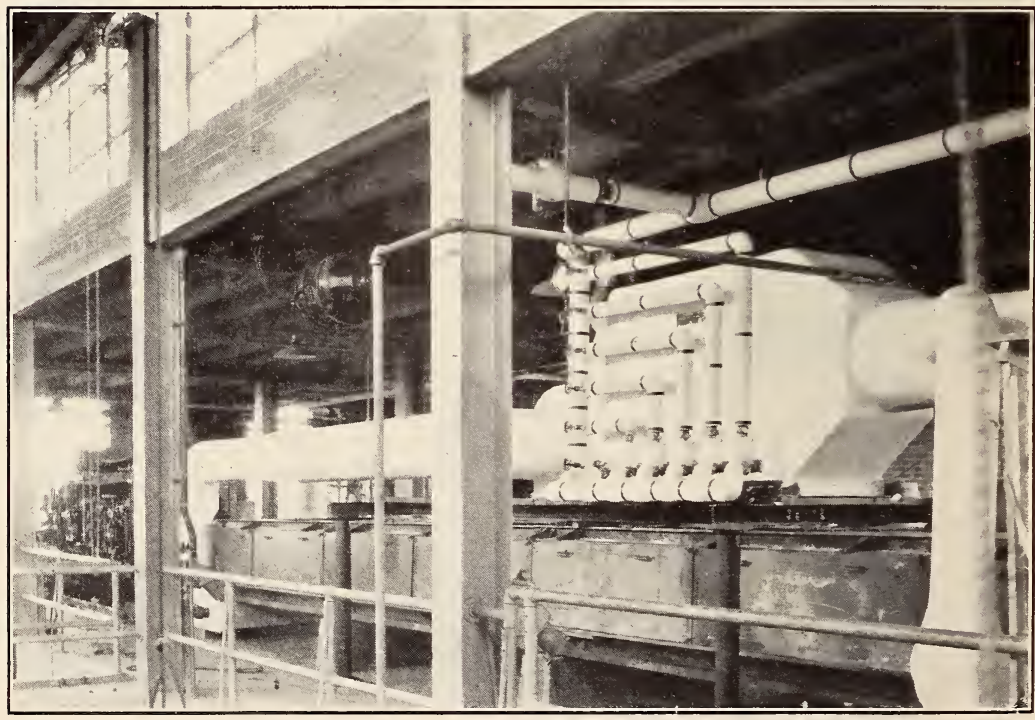

Figure 12.-Drier 
through an automatic valve that as they revolve upward they are first connected to a vacuum pump and then to a compressed-air supply. The suspension of pulp in water flows into the space between the cylinder and the side of the containing tank. The water is sucked into the cylinder and a mat of fibers is formed on the screen surface as it revolves. When the compartment carrying the mat reaches the proper point the vacuum is released and, if necessary, compressed air turned on. This loosens the mat, which is stripped off, forming a continuous sheet.

Considerable experimenting was necessary to determine the most satisfactory method of feeding the pulp into the Oliver forming machine. A front feed, or entering box, with an adjustable apron in the rear to regulate the height of stock in the containing vessel was found to give the best results. The agitators prevent settling of the pulp. The Oliver machine was originally equipped with an endless composition belt above the cylinder, for the purpose of smoothing out the newly formed mat. This was replaced by a felt belt with better results. Various devices were tried in stripping off the mat cleanly from the cylinder, but a simple plate "doctor" was finally adopted. The only defects noticed in the mat were cracks produced occasionally by the suction partition in the cylinder. If the cylinder screen is kept clean and the pulp is of proper tenacity, the mat strips off instead of being plowed off, and little difficulty is experienced.

In the operation of the board-forming machine it should be fed with pulp of a consistency of from 1.5 to 2.5 per cent. The exact figure must be determined for the individual plant after it is assembled. It is important that all of the screens of the wet end of the forming machinery be kept clean. In this connection, the addition of a spray or shower pipe at the front of the Oliver machine under the "doctor" is quite helpful, but care should be taken not to use too much water, as undue dilution of the pulp is harmful. Any segregation of fibers in the bottom of the Oliver machine tends to affect the surface of the board. For this reason means should be provided for removing the segregated material. Both the dam and the agitator at the back of the Oliver should be adjustable, since the formation of the board depends a great deal on the proper height of the dam. It is advisable to have a slow stream of pulp spilling over the back of the dam and returning to the stuff chest.

The proper freeness is wholly empirical. Once the operating details are worked out, the freeness can be checked frequently, and in this way the thickness of pulp on the forming machine can be controlled and kept uniform.

\section{FORMING THE BOARD}

As it leaves the forming machine the mat is loosely formed and contains a great excess of water. Some of this water can be pressed out, which, of course, is cheaper than evaporating it. By subjecting the mat to pressure to remove this water, the fibers are compacted sufficiently so that the sheet can be handled into the drier without further difficulty. The more pressure exerted, the more water will be removed, and therefore, the less expensive will be the subsequent drying operation. But if the fibers are compacted too much, the 
density of the board will be increased and its value as an insulator correspondingly diminished.

The pressing machine used (shown in fig. 11) consists of three sets of heavy rolls in series, the greatest pressure being obtained on the last set of rolls. Ordinary paper-makers' felt supports the board through the rolls to the drier. The press rolls and Oliver machine are driven from a common motor. In order to provide for such adjustment of speed as is necessary for perfect synchronization, the press rolls and Oliver machine are belted together by a belt running on cone pulleys.

In practical operation three sets of press rolls are not enough. Five or six sets of rolls would be preferable. There is a tendency for the water to squeeze past the end of the rolls and run back on the board, thereby softening it. Small rolls at an angle of $45^{\circ}$ pressing against the outer edge of the felts cause this water to spill off. A small suction tube should be placed behind each press roll to prevent water from sinking back into the board and softening it. The water should be carried away from the bottom of the squeeze rolls and not allowed to run back into the felt. A satisfactory combination of form roll felts is a fine meshed wire or closely woven felt for the upper felt and a very coarsely woven felt for the bottom. This gives two surfaces on the board; a smooth suriace to be used as the finished wall surface and a rough surface to be used as a plaster base. The rough surface is also preferred by many interior decorators for certain decorative effects. A thicker film of air held by the rough surface may give a better insulation.

In general, the pressure applied on the press rolls is sufficient to reduce the moisture content to 70 per cent. Boards with a moisture content of only 60 per cent have been produced. One commercial plant using a modified garbage press is said to reduce the moisture to 60 per cent. For the same type of board, the greater the pressure the stronger the board and the lower the insulating value.

\section{DRYING}

Drying is necessarily the final step in the process of manufacture. Commercial driers are of two types-the single deck, wherein the board is run in a continuous sheet from the forming machine, the dried board being cut into lengths as it emerges from the drier; and the multiple deck, wherein the board is cut into lengths first, the boards being fed automatically to the different decks of the drier in rotation.

The drier used in this work (shown in fig. 12) is of the roller type, 54 feet long by 6 feet wide. The boards are carried between two sets of rollers in a chamber heated by steam coils. The board is carried along on the lower set, while the upper set tends to prevent warping. Since the tendency for cornstalk board to warp is slight, there is no great need for the upper rolls. Air is heated by additional coils outside and circulated through the drier by a blower. The drier has heavily insulated walls at top, bottom, and sides to minimize heat losses.

Two methods of drying were used. When a piece longer than 4.5 feet was desired the board was run directly from the press rolls to the drier. In order to do this the drier was synchronized in linear 
speed with the Oliver machine and the press rolls. After a board the length of the drier was run into it the machinery was stopped and the board allowed to dry.

When it was desired to make a greater quantity of board another procedure was used. The connection rollers between the press rolls and drier were removed and replaced by a set of idler rolls mounted on a framework and accommodating a length of 4.5 feet of board. The wet board was run continuously onto the idler rolls and cut off into 4.5 -foot lengths, which were slid into roller trays supported at the end of the idler rolls. The trays containing the sheets of board were stacked up until all of the board was formed. The drier was then started and the sheets of board slid off the roller trays onto the drier rollers. Two rows of board were run through the drier simultaneously. The drier was run at a speed low enough to dry the boards in one passage. The drying temperature generally used was from $200^{\circ}$ to $260^{\circ} \mathrm{F}$., or much lower than would be used in commercial practice, and the time required for drying was about three and one-half hours. Other experiments showed that the time required for drying cornstalk board one-half inch thick at a commercial temperature of about $320^{\circ} \mathrm{F}$., is approximately two and one-third hours.

A small circular saw was used for cutting and trimming the board. There are several commercial devices available for this purpose. The board, when trimmed, was 2 feet wide and of varying length.

The finished board, when in equilibrium with the surrounding air, has a normal moisture content of 7 to 12 per cent. There is therefore nothing to be gained by drying it beyond this point. It is generally necessary to overdry the board, however.

\section{COATING}

Unless the manufacturing operations, and particularly the sizing, are carefully controlled, the surface of cornstalk wall board is apt to "dust." In an attempt to overcome this, a study was made of various surface coatings which might be applied to the board after manufacture.

A number of experiments indicated that a 4 per cent solution of either glue or starch, applied by means of a spray gun at the rate of 2 pounds of dry material per 1,000 square feet of board would have the desired effect. Other properties of the board are not materially changed by this treatment.

It was later found that if the pulp is of the proper freeness and is properly sized, this dusting would not occur. Since prevention is always better than cure, further work on coating was abandoned.

\section{TESTING AND CONTROL METHODS}

The test methods used for final judgment of the quality of the product were always those which are generally accepted by the paper industry. For mill control, however, adaptations were devised which are less laborious than the standard methods and sufficiently accurate for the purpose. 
Consistency.-Four hundred grams of the sample are weighed out and evaporated to dryness at $105^{\circ} \mathrm{C}$. The consistency is expressed as the percentage of dry fiber present. There is a slight error due to the dissolved matter in the water, which is weighed with the dry fibers. Attempts to filter off or decant part of the water before evaporating were unsuccessful. Owing to the colloidal nature of the pulp, filtration takes place very slowly so that no time is saved, and it is also difficult to remove the fibers from the filter paper.

Freeness.-A pulp consistency of 0.5 per cent is used at a temperature of $23^{\circ} \mathrm{C}$. One liter of the sample is used, the freeness being measured by the time in seconds required for $500 \mathrm{ml}$ of water to drain through the freeness tester. This tester consists of a cylindrical vessel $2 \frac{1}{2}$ inches in diameter, to one end of which is soldered a No. 80 screen, the opening being 2 inches in diameter. A cap fits over the bottom of the tester, which is removed as soon as the pulp is poured in. The time is measured by a stop watch, and is reported in seconds.

Determination of hydrogen ion concentration.-This was first determined colorimetrically by using the usual indicator method with solutions made up in the laboratory. This involved extensive work and gave unsatisfactory results. A set of commercial buffer color standards having a $\mathrm{pH}$ range of 3.0 to 7.6 was tried. This gave satisfactory results with clear liquids, but not in turbid or highly colored liquids. The quinhydrone electrometric method was adopted in preference to the hydrogen electrode method because of its simplicity and rapidity of operation. Unlike the hydrogen electrode the quinhydrone electrode is not easily poisoned. The set should be checked occasionally by using an $\mathrm{M} / 20$ solution of acid potassium phthalate which should give a $\mathrm{pH}$ of 3.97. All of the data are based on a temperature of $20^{\circ} \mathrm{C}$. Any considerable variation from this temperature will affect the accuracy of the results. At ordinary room temperature no temperature correction is necessary.

Strength test.- The strength is expressed as the modulus of rupture as calculated from the results of a transverse test by the usual formula-

where-

$$
M=\frac{3}{2} \frac{W l}{b d^{2}}
$$

$M=$ transverse strength in lbs./in. ${ }^{2}$.

$W=$ breaking load.

$l=$ length between supports.

$b=$ breadth of sample.

$d=$ depth of sample (thickness of board in inches).

\section{PROPERTIES OF CORNSTALK INSULATING BOARD}

From the hundreds of experiments which have been conducted, the data in the following table have been selected as illustrative of the results obtained. 
TABLE 1.-Cornstalk insulating board from mechanical pulp. Pulp made in Hollander beater

\begin{tabular}{|c|c|c|c|c|c|c|c|c|c|c|c|c|}
\hline \multicolumn{2}{|c|}{$\begin{array}{l}\text { Beating treat- } \\
\text { ment }\end{array}$} & \multicolumn{3}{|c|}{$\begin{array}{l}\text { Sizing (per cent by } \\
\text { weight of dry fiber) }\end{array}$} & \multicolumn{3}{|c|}{ Properties of pulp } & \multicolumn{2}{|c|}{ Water in sheet } & \multicolumn{3}{|c|}{ Properties of board } \\
\hline $\begin{array}{l}\text { Dura- } \\
\text { tion of } \\
\text { beat- } \\
\text { ing }\end{array}$ & $\begin{array}{l}\text { Dura- } \\
\text { tion of } \\
\text { wash- } \\
\text { ing }\end{array}$ & $\begin{array}{c}\text { Rosin } \\
\text { size }\end{array}$ & Alum & Glue & $\mathrm{pH}$ & $\begin{array}{l}\text { Con- } \\
\text { sist- } \\
\text { ency }\end{array}$ & $\begin{array}{l}\text { Free- } \\
\text { ness }\end{array}$ & $\begin{array}{l}\text { As it } \\
\text { leaves } \\
\text { mat- } \\
\text { form- } \\
\text { ingma- } \\
\text { chine- }\end{array}$ & $\begin{array}{l}\text { As it } \\
\text { leaves } \\
\text { board- } \\
\text { form- } \\
\text { ingma- } \\
\operatorname{chine}-\end{array}$ & \begin{tabular}{|} 
Trans- \\
verse \\
strength
\end{tabular} & $\begin{array}{l}\text { Thick- } \\
\text { ness }\end{array}$ & $\begin{array}{c}\text { Weight } \\
\text { (pounds } \\
\text { per } \\
1,000 \\
\text { square } \\
\text { feet } \\
1 / 2 \text {-inch } \\
\text { thick) }\end{array}$ \\
\hline $\begin{array}{l}\text { Hours } \\
6\end{array}$ & $\begin{array}{l}\text { Hours } \\
-\end{array}$ & & & & 7. 00 & $\begin{array}{c}\text { Per cent } \\
2.02\end{array}$ & Seconds & $\left|\begin{array}{c}\text { Per cent } \\
72.6\end{array}\right|$ & $\begin{array}{c}\text { Per cent } \\
70.2\end{array}$ & Lbs./in. ${ }^{2}$ & Inches & \\
\hline $\begin{array}{l}13 \\
13 \\
7 \\
5 \\
5 \\
4.5 \\
4 \\
4 \\
3.25\end{array}$ & \begin{tabular}{r}
0.5 \\
6.0 \\
3.0 \\
3.0 \\
3.5 \\
3.0 \\
\hdashline.-- \\
.-- \\
-0
\end{tabular} & $\begin{array}{l}3 \\
3 \\
4 \\
2 \\
2 \\
2 \\
2 \\
2 \\
2\end{array}$ & $\begin{array}{l}4.5 \\
4.5 \\
5.0 \\
4.0 \\
5.0 \\
5.0 \\
5.0 \\
5.0 \\
5.0\end{array}$ & $\begin{array}{l}-. \\
- \\
- \\
- \\
- \\
- \\
--\end{array}$ & $\begin{array}{l}\text { 7. } 00 \\
4.80 \\
4.95 \\
4.50 \\
5.10 \\
4.60 \\
4.90 \\
4.60 \\
4.60 \\
4.60\end{array}$ & $\begin{array}{l}2.00 \\
2.22 \\
2.09 \\
2.49 \\
1.80 \\
2.38 \\
2.87 \\
2.27 \\
2.29\end{array}$ & $\begin{array}{r}346 \\
284 \\
1,000 \\
409 \\
536 \\
1,000 \\
448 \\
511\end{array}$ & $\begin{array}{l}84.1 \\
84.5 \\
87.2 \\
88.2 \\
85.8 \\
87.7 \\
87.1 \\
86.5 \\
86.6\end{array}$ & $\begin{array}{l}81.4 \\
72.6 \\
68.7 \\
76.7 \\
73.9 \\
72.0 \\
73.7 \\
74.4 \\
75.9\end{array}$ & $\begin{array}{l}247 \\
225 \\
225 \\
170 \\
235 \\
234 \\
236 \\
232 \\
200\end{array}$ & $\begin{array}{l}5 / 16 \\
17 / 32 \\
1 / 2 \\
1 / 2 \\
5 / 8 \\
1 / 2 \\
7 / 16 \\
13 / 32 \\
1 / 2 \\
5 / 8\end{array}$ & $\begin{array}{l}495 \\
525 \\
635 \\
600 \\
580 \\
635 \\
595 \\
578 \\
552\end{array}$ \\
\hline
\end{tabular}

When the manufacturing conditions had been sufficiently stabilized, samples of the product were sent to Washington for comprehensive tests.

Weight.-The samples of one-half inch board selected had an average weight of 645 pounds per 1,000 square feet. The specification ${ }^{14}$ calls for a minimum of 500 pounds. These particular samples were, therefore, considerably overweight, which is poor from the cost standpoint, and which also probably affected their insulating property adversely.

Transverse strength.-When specimens 3 inches wide were loaded at the center of a 12-inch span it took an average of 7.7 pounds to break them if the samples were cut lengthwise of the board and 7.9 pounds for samples cut crosswise. The specification calls for minima of 10 and 6 pounds, respectively. The samples were, therefore, too weak in the long direction and stronger than necessary in the cross direction.

Expansion.-Samples were conditioned by exposing them for 40 hours in an atmosphere of 30 per cent relative humidity at $70^{\circ} \mathrm{F}$. They were then exposed to saturated air (100 per cent relative humidity) at the same temperature for 72 hours. The average increase in length due to this treatment was 0.52 per cent lengthwise of the board and 0.55 per cent crosswise. The specification places the maximum limit at 0.7 per cent in the crosswise direction, but places no limit on the expansion in the lengthwise direction, because this is found to be always less than the other.

Absorption.-After being conditioned at 30 per cent relative humidity and $70^{\circ} \mathrm{F}$. as above, the samples were immersed for one hour in water at the same temperature and the gain in weight noted. The average absorption was found to be 60 per cent, as compared

${ }^{14}$ B. W. Scribner and F. T. Carson, Specification for Fiber Wall Board, Paper Trade J.; September 26,1929 . 
with a maximum of 65 per cent in one-half hour required by the specification..$^{15}$

Thermal conductivity.-The thermal conductivity of the board as received was found to be 0.39 . This represents the amount of heat in Btu. which will flow in one hour through a square foot of the material, if the temperature drop through the material is $1^{\circ} \mathrm{F}$. per inch thickness. Drying the board at $212^{\circ} \mathrm{F}$. overnight decreased the thermal conductivity to $0.36 \mathrm{Btu} .^{16}$ These figures are about the same as those found for similar commercial boards. ${ }^{17}$

Summary.- It is evident from the above that an insulating board can be made from cornstalks with about the same properties as those of similar boards made from other kinds of raw materials.

The above samples represent the quality of board produced when the mill was first started. Subsequent experiments have resulted in a decided improvement in the quality of the product. These improvements will be described in a report now in preparation.

\section{YIELD}

Commercial considerations require a discussion of the quantity of board produced, as well as its quality. Therefore, when it was found that the equipment was operating to produce board of satisfactory quality, six special runs were made to get information about quantity. The average of these runs shows that a "yield" of 76.9 per cent of the bone-dry weight of the stalks was found in the finished board.

Yield is inextricably associated with the properties of the board. The number of square feet of board that can be made from a ton of stalks depends not only on the yield (as expressed above), but also on the density and thickness of the board. If two boards have the same densities, the thicker will be the better insulator, but it will also require a greater weight of stalks to make an equal area of board and will therefore be the more costly. If two boards have the same thickness, then the denser will be the more costly and the stronger but will be the poorer insulator.

The specification referred to above is the result of a compromise between these conflicting tendencies and fairly represents the properties of boards which are on the market to-day. The chief object is to produce a board which will give the most insulation per unit of cost. This is attained by keeping the weight as low as possible and still have a board strong enough to stand handling in transportation and erection.

\section{RELATED RESEARCHES}

\section{REFRIGERATION BOARD}

The insulating value of a board varies approximately with its thickness. In designing cold-storage warehouses, refrigerators, etc., provision is made for 2 inches or more of insulation in the walls, instead of the customary half-inch thickness of commercial boards.

Two general types of cornstalk refrigeration boards have been developed ${ }^{18}$-laminated and nonlaminated. The laminated boards were produced by cementing together enough of the one-half or

${ }_{15}$ The above four tests were made under the supervision of B. W. Scribner.

16 Tests made under the supervision of M. S. Van Dusen.

17 Bureau of Standards Letter Circular No. 227.

$18 \mathrm{By}$ T. Naffziger, of the Iowa Engineering Experiment Station. 
$5 / 8$-inch boards to make up the desired thickness. Both sodium silicate and an adhesive produced from corncobs were used as cementing materials. The former has the advantage of being a standard material readily obtainable, but produced a heavier board. The boards were pressed lightly while the cementing material dried. Boards of this type are much stronger than similar commercial boards and are excellent heat insulators. A method in many respects preferable to cementing is to stitch together with wire the required number of boards. This method has the advantage of preserving intact the air film on the surfaces of the boards, which adds materially to the insulating value.

Nonlaminated boards were made from both mechanical and cooked cornstalk pulp. The mechanical pulp was made up in the same manner as for the standard board. The boards were formed in the large suction machine used for pressed board, and the thick mat was dried in a steam-heated hydraulic press. While drying the upper platen was lowered onto the mat with just sufficient pressure to produce a smooth surface. Since it was difficult to produce the same pressure each time, the density of the boards varied from 5.32 to 32.83 pounds per cubic foot, the lighter boards being less dense than cork. Boards were made in a similar manner from pulp produced by cooking shredded cornstalks one hour with water at 40 pounds steam pressure. The density varied from 5.64 to 8.05 pounds per cubic foot.

Refrigeration boards are subjected frequently to considerable moisture, which is favorable for the growth of mold. Rosin-sized cornstalk board seems to resist molds satisfactorily.

\section{WATERPROOFING}

Commercial insulating board will absorb water when immersed therein, without any permanently harmful effect. It was thought, however, that if cornstalk board could be made waterproof, a wider market for it might be found. To this end, several experiments were tried with various coating and impregnating agents. Best results were obtained with a mixture of carnauba wax and alum. Such materials add seriously to the cost and weight of the board, decrease its insulating value, and are of doubtful durability. It may, therefore, be stated that cornstalk board is not designed to withstand frequent or continuous immersion in water, but that, under some circumstances, a coat of paint of any of the usual types may prove helpful.

\section{FIREPROOFING}

Fibrous insulating boards are not fireproof, and cornstalk board is not much different from the others in this respect. With the thought that a fireproof board would have a wider market, many experiments were made, impregnating the board with various fire-resistant materials. The most effective treatment found consisted of impregnating the board with sodium silicate, which was then precipitated in place by means of alum. Like the waterproofing this treatment increases the weight and the cost of the board and decreases its insulating value. 


\section{COST OF MANUFACTURE}

\section{GENERAL DESCRIPTION}

The equipment of a full-sized mill is much the same as that already described in Section V, except that the items are larger in size or are -duplicated.

The stalks are conveyed to the magnetic separator on a belt conveyor. Just before reaching this machine the bales are broken open. The magnetic separator removes all tramp iron before the stalks reach the shredders. The stalks should be sprayed with water to keep down dust. The shredders reduce the stalks to fibers ranging in length from one-half to $1 \frac{1}{2}$ inches. As the stalks come from the shredder they discharge into a hopper conveyor, which is arranged so that it may unload into any one of the four beaters. As the beater is being loaded with stalks, water is run in and the beating operation is started. When the pulp has been beaten four hours it is pumped into the stock chest. Alum and rosin size are added about one-half hour before the stock is pumped over. In the stock chest the pulp is diluted from the 5 per cent consistency, which it has in the beater, to a consistency of about 1 per cent.

It is then pumped to the mat-forming machine of the singlecylinder suction type described above. The mat then goes through the press rolls of the board-forming machine and is dried in a directheat drier, single deck, 1,100 feet long. An automatic cutting device cuts the dried boards into lengths, after which they are piled on trucks and taken to cars or storage.

Commercial board is 4 feet wide, and the machinery is usually designed to run at a speed of 8 linear feet per minute. The plant has, therefore, been designed on the basis of a production of 32 square feet per minute. This is about the lowest production practicable with standard equipment. Larger production, attained by the use of wider or of duplicate machines, will probably result in lower costs.

\section{EQUIPMENT}

It is believed that a discussion of the manufacturing process should start with the cornstalks in bales at the factory. The harvesting, baling, and collecting of the stalks may be done by the farmers, either individually or cooperatively, or it may be necessary for the manufacturer to finance these operations. In any event, these costs are covered into a single item - the cost of cornstalks delivered at the factory.

From this point on, the following equipment will be required:

Bale-handling equipment and conveyors to move the bales from the stock pile to the factory; a magnetic separator to remove pieces of tramp iron which might damage the equipment; 1 large shredder; four 1-ton Hollander beaters; 1 stock chest, capacity 27,000 gallons; 1 mat-forming machine, 5 feet wide by 8 feet in circumference; 1 board-forming machine, 20 feet long, equipped with five pairs of rolls each 3 inches diameter by 4 feet long; 1 continuous single deck drier, 7 feet wide by 1,100 feet long; 1 automatic cutter and trimmer; the necessary pumps, skids, trucks, motors, and shafting; the necessary storage space for finished board; a railroad siding. 
From estimates obtained during 1928 the cost of this equipment erected in place will be about $\$ 215,000$. This figure must, of course, be taken as informative and not absolute, since the prices of machinery change with time and with the location selected for the factory. This equipment will require 47,250 square feet of floor space.

\section{LABOR AND POWER}

To operate the above equipment the following men will be required per shift:

Two men to handle the bales into the factory; 1 man to operate the shredder; 1 man to operate the beaters; 3 men to operate the mat-forming machine, board-forming machine, and drier; 8 men to handle the finished boards and load cars; total, 15 men and 1 foreman per shift, or 45 men and 3 foremen per day.

The power requirements of the machines are as follows:

H. $\mathrm{P}$.

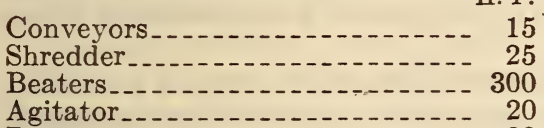

H. $\mathrm{P}$.

5 Mat and board forming machines_ 75

Agitator 20

Pumps.

Cutter

30

530

\section{RAW MATERIALS AND OUTPUT}

A production of 32 square feet per minute equals $46.08 \mathrm{M}$ square feet per day of 24 hours. If the board weighs 600 pounds per $M$, then a day's production will weigh 13.8 tons. With a yield of 75 per cent this will require about 18.5 tons of stalks per day.

This yield is figured on a bone-dry basis for both stalks and board. Since the board will usually contain about 10 per cent water and the stalks somewhat more, some allowance should be made. The average yield found experimentally was about 77 per cent.

The usual bale of cornstalks measures 36 by 18 by 16 inches and weighs 50 pounds. There will be a maximum of six months and a minimum of four months during which stalks can be harvested. Therefore storage space should be provided for eight months' supply. Assuming that the bales are piled to a height of $30 \mathrm{feet}$, this will require an area of 35,600 square feet. While these figures are admittedly rough estimates, they indicate that a rather large factory site is required.

Rosin size and alum are necessary to size the board, the best results being obtained with about 2 per cent of rosin size and 5 per cent of alum, based on the weight of the dry fiber. The factory will, therefore, require 740 pounds of rosin size and 1,850 pounds of alum per day.

A good supply of soft water is one of the essentials for any mill for the manufacture of insulating board or other paper products. The water requirement in the semicommercial mill has been found to be about 3,000 gallons per $M$. At this rate the large mill will require 138,240 gallons per day.

Heat must be supplied to operate the drier. If the finished board is assumed to contain 10 per cent of water and the same board as it entered the drier contained 75 per cent, then the weight of water evaporated in the drier is 1,560 pounds per M. To raise this water from room temperature $\left(70^{\circ} \mathrm{F}\right.$.) to the boiling point and evaporate 
it will require 1,112 Btu. per pound, 1,735,000 Btu. per M, 79,964,$000 \mathrm{Btu}$. per day. This is about $2 \frac{1}{2}$ tons of good coal per day, provided that the drier is 100 per cent efficient. Since the efficiency will depend upon the kind of fuel used, the type of drier, and the way in which it is installed and operated, it seems hardly worth while to carry these figures further.

At the prices prevailing at Ames, Iowa, in 1928 it will take the gross income from $16.5 \mathrm{M}$ of board to pay the fixed daily charges for raw material, power, and labor. The rest of the daily production, 29.58 M, must provide for the overhead, depreciation, and profits.

\section{OVERHEAD}

Overhead is admittedly a large item in the cost of any manufactured product. It varies so greatly with time, with locality, and with the conditions of individual plants that any attempt to set up specific figures for general application would be unwise. Therefore remarks under this head will be confined to a few general precautionary statements.

No fire-insurance rates on baled cornstalks are at present available. The Western Actuarial Bureau is at present cooperating in experiments to ascertain the fire hazard. Under existing conditions, therefore, cornstalks will take a base rate of $\$ 3$, with additions or deductions, depending upon their proximity to extra fire hazards or extra protection. There are many patents which may be construed to have a bearing on this process. All developments made by this bureau are free to the public. Investigational work and a fund to take care of obsolescence of equipment should be provided for.

A careful analysis of the figures at hand leads to the belief that under the proper conditions insulating board can be made from cornstalks at a reasonable profit to both the manufacturer and the farmer.

\section{USES, STATISTICS, AND POSSIBLE COMPETITION}

\section{USES}

Insulating boards made of materials other than cornstalks have been on the market for some years. While developed primarily as insulating materials, they have found many other uses. They are now competing with lumber as sheathing and roofing for houses. In the better constructions, the insulating board is covered with some material to protect it from the weather, but in cheap temporary buildings a coat of paint is sometimes deemed sufficient.

For interior partitions and walls, insulating board is now competing with lath as a base for plaster. The plaster may be omitted, and the surface of the board may be decorated or left in its natural condition.

Insulating board has great value as an acoustic material, and special boards have been developed for this purpose.

Linings for refrigerating cars, household refrigerators, and coldstorage plants form another market which is now consuming millions of square feet of insulating board annually.

This board is also finding considerable favor as the material for odd jobs around the house, such as ceiling the attic, building closets or tool sheds, inclosing porches, and the like.

For some of these purposes, where properties other than insulating value are of importance, it has been found advantageous to make 
board of a somewhat different quality, as, for example, making a denser board, which will be somewhat stronger, and therefore more suitable for use as sheathing.

\section{STATISTICS}

Unfortunately for our present purposes, the census figures do not carry fiber insulating board as a separate item. This material is included partly under "paper-mill products" and partly under "wall plaster, wall board, and floor composition." A careful analysis of the subheads under these titles indicates a production of about $570,000,000$ square feet of insulating board in 1927, and that the industry has been growing very rapidly. After visiting most of the operating factories during the summer of 1928 , G. M. Rommel estimated the production at about 750,000,000 square feet in 1929 .

The census figures show that about $46,000,000$ square feet of "wall board" were exported during 1927. Some of this was undoubtedly insulating board.

The department of research in lumber retailing, Antioch College, Yellow Springs, Ohio, and the Ohio Association of Retail Lumber Dealers conducted a survey as to the consumption of sized insulating boards in the Central States. As stated in a news release of March 27, 1928 , the purpose of the survey was primarily to determine to what extent insulating boards were replacing lumber sheathing. In part it states:

While exact data is not available it is probable that by far the largest amount of insulating board was used as a substitute for sheathing, a small amount was used as insulation, in addition to lumber sheathing for exterior wall covering, and a lesser amount as a plaster base nailed to the inside of the studding.

Of the firms reporting in the comparatively small territory covered by the inquiry, only $32 \frac{1}{2}$ per cent handled insulating board in 1925 , while 60 and 72 per cent, respectively, handled it in 1926 and 1927. The release further reads:

Retail lumbers dealers as a class are not unfavorable to the handling and use of wall boards, although there is a small minority of dissenting voices who hold to lumber. This class is rapidly disappearing. It may, however, be added that the introduction and the phenomenal growth of business in insulating materials is not due to the retailer, as much as to an aggressive campaign of general advertising. *** If comments on the cards mean anything, dealers as a whole are not pushing insulating boards, manufacturers are doing the selling. The prejudice against lumber substitutes prevails among the older retailers.

The volume of insulating boards sold from 1925 to 1927 exhibits a steady increase; for taking the number of square feet handled in 1925 at 100, then the figures 143 and 208 represent the volume of sales for 1926 and 1927, respectively.

When considering the possible market for insulating board in the erection of new dwellings it was learned that new houses were provided for 406,095 families in $1927 .{ }^{29}$ Although these figures include some buildings for which permits are issued but which are not constructed, they cover only a part of the total construction of new dwellings. During the past few years the total number of families accommodated in new dwelling construction is estimated as well over 500,000 annually. Assuming, for the purpose of making rough calculations, that this construction is equivalent to 300,000 houses, each having a ground area of 25 by 30 feet, and two stories high, the

${ }^{19}$ Building permit figures of the Bureau of Labor Statistics. 
possible consumption of insulating board for residential building in a construction year similar to 1927 might be estimated as follows:

300,000 houses, with attic floor insulation (average size 750 square feet) 300,000 houses, with walls insulated ( 2,000 square feet average). 300,000 houses, with roofs insulated (945 square feet average size)

Square feet

houses with walls and attic, floor and roof insulated -0

It is estimated that there are somewhat over 24,000,000 dwellings now occupied. A serious attempt to provide all of these dwellings with insulation would create an enormous demand for insulating board.

The present output of insulating board is thus seen to be less than the amount which could be used in the construction of new dwellings alone. If an equal amount were used in the repair of old dwellings, and a third like amount were provided for other uses, such as lining refrigerator cars, the total consumption might be upward of $3,000,000,000$ feet per year. This increase over present production would call for 145 plants of the size described in this article and would provide an outlet for 600,000 tons of cornstalks, which represent about half the amount that is readily available.

\section{POSSIBLE COMPETITION}

Two types of insulating board are on the market-the rigid type and the flexible type. Rigid board is now being made from bagasse, wheat straw, cornstalks, licorice-root waste, sawmill waste, groundwood screenings, and cull wood. As a rule, boards made from crop by-products are lighter in weight than those made from wood products, while the latter have more structural strength.

The only other crop producing cellulosic waste comparable in amount with that from the corn plant is our timber crop. It is estimated that this waste amounts to about $125,000,000$ tons annually. ${ }^{20}$ A considerable proportion of this is sawdust and slabs, already collected at the mills. The rest consists of small stuff, tops, stumps, etc., now mostly left in the forest, but which could be collected at about the same cost as merchantable timber, or perhaps a little less, if the reduction of the fire hazard is allowed for. On this assumption a careful survey of the situation shows that in proximity to the forests this timber waste can be collected and delivered at a less cost than cornstalks per ton of dry fiber.

The timber waste is now located chiefly in the Gulf and Pacific Coast States. In the Corn Belt, therefore, cornstalk board would have a considerable advantage in freight rates over wood-pulp board.

Most of the other materials from which insulating board can be or is being made are of such a nature that the requisite tonnage can be found in only a limited area. Some of these are in the fortunate position of having the cost of harvesting and collecting the fiber borne by another part of the plant. With others it would seem that these costs are about the same as those for cornstalks, with possible variations due to differences in yield per acre.

${ }^{20}$ LLetter from Forest Service, Nov. 15, 1928. 
Transportation charges determine in part whether the insulating board used in any given market can be made of fibrous material which is locally available. In this statement, the term "locally" must be considered in connection with future plans for cheap water transportation and should be measured in dollars of freight charge and not in miles

Washington, April 30, 1930 
